Article

\title{
Novel Amino Acid Derivatives of Quinolines as Potential Antibacterial and Fluorophore Agents
}

\author{
Oussama Moussaoui ${ }^{1, *}$, Rajendra Bhadane ${ }^{2,3}{ }^{\circledR}$, Riham Sghyar ${ }^{1}$, El Mestafa El Hadrami ${ }^{1}$, \\ Soukaina El Amrani ${ }^{4}$, Abdeslem Ben Tama ${ }^{1}$, Youssef Kandri Rodi ${ }^{1}$, Said Chakroune ${ }^{1}$ \\ and Outi M. H. Salo-Ahen $2,3, *$ (D) \\ 1 Laboratory of Applied Organic Chemistry, Faculty of Sciences and Techniques, \\ Sidi Mohamed Ben Abdellah University, Fez 30000, Morocco; riham.sghyar@usmba.ac.ma (R.S.); \\ elmestafa.elhadrami@usmba.ac.ma (E.M.E.H.); abdeslem.bentama@usmba.ac.ma (A.B.T.); \\ youssef_kandri_rodi@yahoo.fr(Y.K.R.); said.chakroune@usmba.ac.ma (S.C.) \\ 2 Structural Bioinformatics Laboratory, Faculty of Science and Engineering, Biochemistry, \\ Åbo Akademi University, FI-20520 Turku, Finland; rajendra.bhadane@abo.fi \\ 3 Pharmaceutical Sciences Laboratory, Faculty of Science and Engineering, Pharmacy, \\ Åbo Akademi University, FI-20520 Turku, Finland \\ 4 Laboratory of Materials, Processes, Catalysis and Environment, \\ Bioindustry and Agri-Food Technology team, Higher School of Technology, \\ Sidi Mohamed Ben Abdellah University, Fez 30000, Morocco; Soukaina.ElAmrani@usmba.ac.ma \\ * Correspondence: oussama.moussaoui1208@gmail.com (O.M.); outi.salo-ahen@abo.fi (O.M.H.S.-A.); \\ Tel.: +212-654496534 (O.M.); +358-22154009 (O.M.H.S.-A.)
}

Received: 6 October 2020; Accepted: 11 November 2020; Published: 1 December 2020

\begin{abstract}
A new series of amino acid derivatives of quinolines was synthesized through the hydrolysis of amino acid methyl esters of quinoline carboxamides with alkali hydroxide. The compounds were purified on silica gel by column chromatography and further characterized by TLC, NMR and ESI-TOF mass spectrometry. All compounds were screened for in vitro antimicrobial activity against different bacterial strains using the microdilution method. Most of the synthesized amino acid-quinolines show more potent or equipotent inhibitory action against the tested bacteria than their correspond esters. In addition, many of them exhibit fluorescent properties and could possibly be utilized as fluorophores. Molecular docking and simulation studies of the compounds at putative bacterial target enzymes suggest that the antimicrobial potency of these synthesized analogues could be due to enzyme inhibition via their favorable binding at the fluoroquinolone binding site at the GyrA subunit of DNA gyrase and/or the ParC subunit of topoisomerase-IV.
\end{abstract}

Keywords: alkaline hydrolysis; amino acid derivative; antibacterial activity; DNA gyrase; enzyme inhibitor; fluorescence; molecular docking; molecular dynamics simulation; quinoline carboxamide; topoisomerase-IV

\section{Introduction}

Antibacterial compounds have been protecting human society from serious bacterial infections for almost 70 years. However, increased antibacterial resistance poses a big threat for the effectiveness of existing antibacterial agents. Hence, there is an urgent need for the development of novel and improved antibacterial compounds [1].

Quinolones represent one of the oldest classes of synthetic antibacterial compounds with a broad spectrum of activity. Originally, they were developed from the narrow-spectrum prototype of quinolones, nalidixic acid, which was reported in 1962 [2]. In the late-1970s and 1980s, the development of fluoroquinolones considerably improved the antibacterial activity of this class 
of antibiotics, broadening their spectrum from Gram-negative bacteria to Gram-positive strains and to Mycobacterium tuberculosis [3,4], along with enhanced pharmacokinetic and pharmacodynamic properties [5,6]. Due to their various beneficial properties in the clinic, fluoroquinolones have been widely used for a range of therapeutic indications, including urinary and respiratory tract infections, skin and soft tissue infections, eye infections, bone and joint infections, intra-abdominal infections and sexually transmitted diseases [7,8].

So far, there are only around 40 bacterial targets that have been exploited by commercial antibiotics [9] Most of the "good" targets for successful antibacterial therapy are molecules involved in essential bacterial functions. Quinolones are known to inhibit two topoisomerase type II enzymes: DNA gyrase and topoisomerase IV, thus blocking bacterial DNA synthesis [7]. In general, these enzymes are found in both Gram-positive and Gram-negative bacteria and depending on the host organism and the quinolone used for the treatment, either of the enzymes can act as the main target of the particular drug [10]. This ability to inhibit two essential enzymes, instead of only one, makes quinolones successful in systemic monotherapy and the incidence of single-step mutations causing high-level resistance in vitro is rare in their case [11] However, extensive use of fluoroquinolones in human and veterinary medicine has also led to a steadily increasing bacterial resistance against these drugs [12-15].

Therefore, in recent years several attempts have been made to develop novel analogues of quinolones. For example, the 2-keto group of quinazolinediones was shown to form an additional hydrogen bond to a conserved arginine residue at the topoisomerase IV fluoroquinolone binding site, whilst the 4-keto-3-acid moiety (of fluoroquinolones) associated with the interactions important for the development of quinolone resistance is not present in these compounds [10] Thus, 2-quinolones, which are isomeres of 4-quinolones (such as ciprofloxacin, a fluoroquinolone) and bioisosteres of coumarins (such as novobiocin which binds to the DNA gyrase ATP-binding site at the DNA gyrase subunit B, GyrB), could serve as potential scaffolds for improved antibacterials. Various 2-quinolone derivatives have been shown to exhibit antimicrobial activities [16-21] Very recently, Xue et al. [22] reported a series of $N$-thiadiazole-4-hydroxy-2-quinolone-3-carboxamides as potential inhibitors of Staphylococcus aureus GyrB.

On the other hand, essential amino acids have been used as major constituents of many drugs, such as $\beta$-lactam antibiotics [23] and glutamate antagonists [24]. Particularly, the aromatic amino acids tyrosine, phenylalanine and tryptophan are well known for their important role in living organisms and they convey a wide range of therapeutic activities [25], including antioxidant activity [26]. Amino acids are non-toxic and have at least two functional groups, the carboxylic group and the amino group that can easily be coupled to a biologically active nucleus, such as a quinolone ring. In recent years, modifications of amino acids have been explored by coupling them with other bioactive compounds such as cinnamic acid [27] or coumarin [28], to study their biological and pharmacological activities. For example, Shivaraj et al. (2013) [29] reported a series of primary amine-based quinoline-6-carboxamides that exhibit antibacterial activity in vitro against Escherichia coli and S. aureus. 2-oxo-1,2-dihydroquinoline-4-carboxylic acid.

Therefore, the aim of this study was to synthesize a novel series of amino acid derivatives of 2-quinolones (specifically, 2-oxo-1,2-dihydroquinoline-4-carboxylic acids), from a set of corresponding amino acid esters and to evaluate their antimicrobial activity against E. coli, S. aureus, Pseudomonas aeruginosa and Bacillus subtilis strains. Moreover, since quinolines and their derivatives can form conjugated systems due to their electronic structure $[21,30]$ we investigated the compounds' fluorescent properties. In addition, molecular docking and molecular dynamics (MD) simulations were used to predict the compounds' binding interactions at the selected putative bacterial targets, DNA gyrase and topoisomerase-IV. The results suggest that these 2-quinolone derivatives could serve as potential starting points for the development of novel antibacterial agents. 


\section{Materials and Methods}

\subsection{Experimental}

Materials: The different reagents used in the synthesis (e.g., triethylamine $99.5 \%$, thionyl chloride $\left(\mathrm{SOCl}_{2}\right) 98 \%$ and amino acids $99 \%$, sodium hydroxide pellets $\left.(\mathrm{NaOH}) 99.99 \%\right)$ and analytical solvents (e.g., tetrahydrofuran 99.5\%, anhydrous dimethylformamide 99.8\%, ethyl acetate (HPLC-grade) and hexane (HPLC-grade)) were purchased from Sigma-Aldrich (St. Louis, MO, USA).

General procedure for the preparation of 2-oxo-1,2-dihydroquinoline-4-carboxamide esters, 1a-2e: A mixture of $1.2 \mathrm{~mol}$ of thionyl chloride $\left(\mathrm{SOCl}_{2}\right)$ and $1 \mathrm{~mol}$ of 2-oxo-1,2-dihydroquinoline-4-carboxylic acid was refluxed for $2 \mathrm{~h}$. The excess of thionyl chloride was evaporated under reduced pressure, then $1.5 \mathrm{~mol}$ of protected amino acid solubilized in $20 \mathrm{~mL}$ of DMF and $3.3 \mathrm{~mol}$ of triethylamine (TEA) were added in small amounts to the mixture. After $20 \mathrm{~min}$, the reaction was abandoned at room temperature for $12 \mathrm{~h}$.

General synthetic procedure for the preparation of 2-oxo-1,2-dihydroquinoline-4-carboxamide acids, 3a-e and 4a-e: A mixture of quinoline carboxamide esters 1a-e and $2 \mathbf{a}-\mathbf{e}(1 \mathrm{~mol})$ and $1.2 \mathrm{~mol}$ of sodium hydroxide in $20 \mathrm{~mL}$ of $\mathrm{THF} /$ water $(1 / 2: v / v)$ was stirred at room temperature for $24 \mathrm{~h}$. After the THF was evaporated, the aqueous solution was extracted 3 times by dichloromethane (DCM) to remove the amount of ester that did not react. Half of the aqueous phase was evaporated and acidified by $\mathrm{HCl}$ (3 M) to obtain precipitate, and the crude product was isolated through simple filtration.

Chromatographic analyses: Column liquid chromatography was performed on 60 Merck silica gel (230-400 mesh ASTM). Thin layer chromatography (TLC) was performed on Merck aluminium plates coated with 60 F254 Merck silica gel (thickness $0.2 \mathrm{~mm}$ ). The synthesized compounds were revealed by an ultra-violet lamp set at $254 \mathrm{~nm}$ and their melting points were determined by Electrothermal IA 9000 Series digital fusiometer using capillary tubes.

Spectroscopic analyses: NMR spectra and electrospray ionization time-of-flight (ESI-TOF) mass spectra were recorded at the Department of Chemistry, University of Helsinki, Finland. Fluorescence spectra were generated at the Department of Chemistry, University of Mulhouse France. NMR spectra were performed on Bruker Ascend 400 MHz-Avance III HD NMR spectrometer (Bruker Corporation, Billerica, MA, USA). ${ }^{1} \mathrm{H}$ NMR spectra were recorded at $400 \mathrm{MHz}$, and the ${ }^{13} \mathrm{C}$ NMR spectra at $100 \mathrm{MHz}$ using DMSO- $\mathrm{d}_{6}$ or $\mathrm{CDCl}_{3}$ as solvent. Recorded spectra were calibrated by solvent signals when applicable and processed with MesterNova software. The chemical shift $(\delta)$ of different peaks was expressed in ppm and the coupling constants $\left({ }^{\mathrm{n}} \mathrm{J}\right)$ in $\mathrm{Hz}$. In describing the multiplicity of signals, the following abbreviations have been used: singlet (s), doublet (d), doublet of doublet (dd), multiplet $(\mathrm{m})$, triplet $(\mathrm{t})$ and quadruplet $(\mathrm{q})$. High-resolution mass spectra were measured by Bruker micro TOF-MS.

2-(2-oxo-1,2-dihydroquinoline-4-carboxamido)propanoic acid: 3a. White solid, $\mathrm{mp}=246-248{ }^{\circ} \mathrm{C}$. ${ }^{1} \mathrm{H} \mathrm{NMR} \delta(\mathrm{ppm}) 400 \mathrm{MHz}, \mathrm{DMSO}-\mathrm{d}_{6}: 12.22\left(\mathrm{~s}, 1 \mathrm{H}, \mathrm{NH}_{\text {quinoline }}\right), 9.1\left(\mathrm{~s}, 1 \mathrm{H},{ }^{3} \mathrm{~J}_{\mathrm{H}-\mathrm{H}}=6.9 \mathrm{~Hz}, \mathrm{NH}\right)$, 7.75-7.21 (m, 4H, $\left.\left.\mathrm{H}_{\mathrm{ar}}\right)\right), 6.57\left(\mathrm{~s}, 1 \mathrm{H}, \mathrm{CH}_{\text {ethylenic }}\right), 4.44\left(\mathrm{qd}, 1 \mathrm{H},{ }^{3} \mathrm{~J}_{\mathrm{H}-\mathrm{H}}=7.2 \mathrm{~Hz},{ }^{3} J_{\mathrm{H}-\mathrm{H}}=6.9 \mathrm{~Hz},{ }^{*} \mathrm{CH}-\mathrm{N}\right)$, 4-3(m, $\mathrm{OH}_{\text {acid }}$ and water), $1.38\left(\mathrm{~d}, 3 \mathrm{H}, \mathrm{CH}_{3}\right) .{ }^{13} \mathrm{C} \mathrm{NMR} \delta(\mathrm{ppm}) 100 \mathrm{MHz}, \mathrm{DMSO}-\mathrm{d}_{6}: 174.2\left(\mathrm{C}=\mathrm{O}_{\text {acid }}\right)$, $166.22\left(\mathrm{C}=\mathrm{O}_{\text {amide }}\right), 161.7\left(\mathrm{C}=\mathrm{O}_{\text {amide quinoline }}\right), 146.5\left(\mathrm{C}_{4 \mathrm{a}}-\mathrm{C}_{8 \mathrm{a}}\right), 139.6\left(\mathrm{C}_{4 \mathrm{a}}-\mathrm{C}_{8 \mathrm{a}}\right), 131.3\left(\mathrm{Ct}_{5}\right), 126.5\left(\mathrm{Ct}_{7}\right)$, $122.4\left(=\mathrm{C}_{3}\right), 120.2\left(\mathrm{Ct}_{6}\right), 116.7\left(\mathrm{Ct}_{4}\right), 116.0\left(\mathrm{Ct}_{8}\right), 48.4\left({ }^{*} \mathrm{CH}-\mathrm{N}\right), 17.0\left(\mathrm{CH}_{3}\right)$. Mass Spectrometry: $m / z=260.1086[\mathrm{M}]^{+}, m / z=519.1848[2 \mathrm{M}+\mathrm{H}]^{+}$.

3-hydroxy-2-(2-oxo-1,2-dihydroquinoline-4-carboxamido)propanoic acid: $3 \mathrm{~b}$. White solid, $\mathrm{mp}=$ 200-202 ${ }^{\circ} \mathrm{C} .{ }^{1} \mathrm{H}$ NMR $\delta(\mathrm{ppm}) 400 \mathrm{MHz}, \mathrm{DMSO}-\mathrm{d}_{6}: 12.1\left(\mathrm{~s}, 1 \mathrm{H}, \mathrm{NH}_{\text {quinoline }}\right), 9.17\left(\mathrm{~s}, 1 \mathrm{H},{ }^{3} J_{\mathrm{H}-\mathrm{H}} 6.9 \mathrm{~Hz}\right.$, $\mathrm{NH}), 7.75-7.21\left(\mathrm{~m}, 4 \mathrm{H}, \mathrm{H}_{\mathrm{ar}}\right), 6.57\left(\mathrm{~s}, 1 \mathrm{H}, \mathrm{CH}_{\text {ethylenic }}\right), 4.5\left(\mathrm{dd}, 1 \mathrm{H},{ }^{3} \mathrm{~J}_{\mathrm{H}-\mathrm{H}}=9 \mathrm{~Hz},{ }^{3} \mathrm{~J}_{\mathrm{H}-\mathrm{H}}=6.9 \mathrm{~Hz},{ }^{*} \mathrm{CH}-\mathrm{N}\right)$, $4.01\left(\mathrm{~d}, 2 \mathrm{H},{ }^{3} \mathrm{~J}_{\mathrm{H}-\mathrm{H}}=9 \mathrm{~Hz}, \mathrm{CH}_{2}-\mathrm{OH}\right) .{ }^{13} \mathrm{C}$ NMR $\delta(\mathrm{ppm}) 100 \mathrm{MHz}, \mathrm{DMSO}-\mathrm{d}_{6}: 173.1\left(\mathrm{C}=\mathrm{O}_{\text {acide }}\right), 166.0$ $\left(\mathrm{C}=\mathrm{O}_{\text {amide }}\right), 161.6\left(\mathrm{C}=\mathrm{O}_{\text {amide quinoline }}\right), 146.4\left(\mathrm{C}_{4 \mathrm{a}}-\mathrm{C}_{8 \mathrm{a}}\right) 139.5\left(\mathrm{C}_{4 \mathrm{a}}-\mathrm{C}_{8 \mathrm{a}}\right), 131.3\left(\mathrm{Ct}_{5}\right), 126.4\left(\mathrm{Ct}_{7}\right), 122.3$ $\left(=\mathrm{Ct}_{\text {ethylenic }}\right), 119.8\left(\mathrm{C}_{6}\right), 116.4\left(\mathrm{Ct}_{4}\right), 115.9\left(\mathrm{Ct}_{8}\right), 61.7\left(\mathrm{CH}_{2}-\mathrm{O}\right), 51.1\left({ }^{*} \mathrm{CH}-\mathrm{N}\right)$. Mass Spectrometry: $m / z=275.0662[\mathrm{M}]^{+}, m / z=551.1409[2 \mathrm{M}+\mathrm{H}]^{+}$. 
2-(2-oxo-1,2-dihydroquinoline-4-carboxamido)-2-phenylacetic acid: $3 \mathrm{c}$. White solide $\mathrm{mp}=218-220^{\circ} \mathrm{C}$. ${ }^{1} \mathrm{H}$ NMR $\delta(\mathrm{ppm}) 400 \mathrm{MHz}, \mathrm{DMSO}_{6}: 13.04\left(\mathrm{~s}, 1 \mathrm{H}, \mathrm{OH}_{\text {acid }}\right), 11.93$ (s, $\left.1 \mathrm{H}, \mathrm{NH}_{\text {quinoline }}\right), 9.52(\mathrm{~s}, 1 \mathrm{H}$, $\left.{ }^{3} J_{\mathrm{H}-\mathrm{H}}=7.3 \mathrm{~Hz}, \mathrm{NH}\right), 7.8-7\left(\mathrm{~m}, 9 \mathrm{H}, \mathrm{H}_{\mathrm{ar}}\right), 6.50\left(\mathrm{~s}, 1 \mathrm{H}, \mathrm{CH}_{\mathrm{ethylenic}}\right), 4.58\left(\mathrm{~d}, 1 \mathrm{H},{ }^{3} \mathrm{~J}_{\mathrm{H}-\mathrm{H}}=7.2 \mathrm{~Hz},{ }^{*} \mathrm{CH}-\mathrm{N}\right)$. ${ }^{13} \mathrm{C}$ NMR $\delta(\mathrm{ppm}) 100 \mathrm{MHz}, \mathrm{DMSO}-\mathrm{d}_{6}: 172\left(\mathrm{C}=\mathrm{O}_{\mathrm{acid}}\right), 166.3\left(\mathrm{C}=\mathrm{O}_{\text {amide }}\right), 161.6\left(\mathrm{C}=\mathrm{O}_{\text {amide }}\right.$ quinoline $), 146.1$ $\left(\mathrm{C}_{4 \mathrm{a}}-\mathrm{C}_{8 \mathrm{a}}\right), 139.6\left(\mathrm{C}_{4 \mathrm{a}}-\mathrm{C}_{8 \mathrm{a}}\right), 1386.7\left(\mathrm{Cq}_{\text {ar phenyl }}\right), 131.2\left(\mathrm{Ct}_{5}\right), 129.0\left(\mathrm{Ct}_{7}\right), 128.6$ (=Ct $\left.\mathrm{Ct}_{\text {ethylenic }}\right), 128.5\left(\mathrm{Ct}_{\text {ar phenyl }}\right)$, $1276.3\left(\mathrm{Ct}_{4}\right), 122.4\left(=\mathrm{Ct}_{\text {ethylenic }}\right), 120.5\left(\mathrm{C}_{6}\right), 116.7(\mathrm{Cq}$ phenyl $), 116.0\left(\mathrm{Ct}_{8}\right), 57.2\left({ }^{*} \mathrm{CH}-\mathrm{N}\right)$. Mass Spectrometry: $m / z=321,0875[\mathrm{M}]^{+}, m / z=643,1801[2 \mathrm{M}+\mathrm{H}]^{+}$.

2-(2-oxo-1,2-dihydroquinoline-4-carboxamido)-3-phenylpropanoic acid: 3d. White solid, $\mathrm{mp}=$ 216-217 ${ }^{\circ} \mathrm{C} .{ }^{1} \mathrm{H}$ NMR $\delta$ (ppm) $400 \mathrm{MHz}, \mathrm{DMSO}-\mathrm{d}_{6}$ : 11.91 (s, $\left.1 \mathrm{H}, \mathrm{NH}_{\text {quinoline }}\right), 9.02\left(\mathrm{~s}, 1 \mathrm{H},{ }^{3} \mathrm{~J}_{\mathrm{H}-\mathrm{H}}=8.4 \mathrm{~Hz}\right.$, $\mathrm{NH}), 7.53-7\left(\mathrm{~m}, 9 \mathrm{H}, \mathrm{H}_{\mathrm{ar}}\right), 6.24\left(\mathrm{~s}, 1 \mathrm{H}, \mathrm{CH}_{\text {ethylenic }}\right), 4.69\left(\mathrm{ddd}, 1 \mathrm{H},{ }^{3} J_{\mathrm{H}-\mathrm{H}}=10.9 \mathrm{~Hz}^{3} J_{\mathrm{H}-\mathrm{H}} 8.3,{ }^{3} J_{\mathrm{H}-\mathrm{H}}\right.$ $\left.4.3 \mathrm{~Hz}{ }^{*} \mathrm{CH}-\mathrm{N}\right), 3.25\left(\mathrm{dd}, 1 \mathrm{H},{ }^{3} J_{\mathrm{H}-\mathrm{H}}=4.8 \mathrm{~Hz},{ }^{2} J_{\mathrm{H}-\mathrm{H}}=13.9 \mathrm{~Hz}, \mathrm{CH}_{2}-\mathrm{Ar}\right), 2.94\left(\mathrm{dd}, 1 \mathrm{H},{ }^{3} J_{\mathrm{H}-\mathrm{H}}=11.1 \mathrm{~Hz}\right.$, $\left.{ }^{2} J_{\mathrm{H}-\mathrm{H}} 13.9 \mathrm{~Hz}, \mathrm{CH}_{2}-\mathrm{Ar}\right) .{ }^{13} \mathrm{C}$ NMR $\delta(\mathrm{ppm}) 100 \mathrm{MHz}, \mathrm{DMSO}-\mathrm{d}_{6}: 173.2\left(\mathrm{C}=\mathrm{O}_{\text {acid }}\right), 166.0\left(\mathrm{C}=\mathrm{O}_{\text {amide }}\right)$, $161.6\left(\mathrm{C}=\mathrm{O}_{\text {amide quinoline }}\right), 146.6\left(\mathrm{C}_{4 \mathrm{a}}-\mathrm{C}_{8 \mathrm{a}}\right), 139.5\left(\mathrm{C}_{4 \mathrm{a}}-\mathrm{C}_{8 \mathrm{a}}\right), 138.4\left(\mathrm{Cq}_{\text {ar phenyl }}\right), 131.3\left(\mathrm{Ct}_{5}\right), 129.6\left(\mathrm{Ct}_{7}\right), 128.6$ $\left(=\mathrm{Ct}_{\text {ethylenic }}\right), 126.9\left(\mathrm{Ct}_{\text {ar phenyl }}\right), 126.4\left(\mathrm{Ct}_{4}\right), 122.3\left(=\mathrm{Ct}_{\text {ethylenic }}\right), 119.8\left(\mathrm{C}_{6}\right), 116.4\left(\mathrm{Cq}_{\text {phenyl }}\right), 115.9\left(\mathrm{Ct}_{8}\right)$, $54.1\left({ }^{*} \mathrm{CH}-\mathrm{N}\right), 36.8\left(\mathrm{CH}_{2}\right)$. Mass Spectrometry: $\mathrm{m} / z=335,1034[\mathrm{M}]^{+}, \mathrm{m} / \mathrm{z}=671,2136[2 \mathrm{M}+\mathrm{H}]^{+}$.

2-(2-oxo-1,2-dihydroquinoline-4-carboxamido)-3-phenylpropanoic acid: 3e. Grey solid, $\mathrm{mp}=$ 203-205 ${ }^{\circ} \mathrm{C} .{ }^{1} \mathrm{H}$ NMR $\delta(\mathrm{ppm}) 400 \mathrm{MHz}, \mathrm{DMSO}_{6}$ : 13.00(s, 1H, OH $\left.\mathrm{OHcid}_{2}\right), 11.94$ (s, $\left.1 \mathrm{H}, \mathrm{NH}_{\text {quinoline }}\right)$, $10.9\left(\mathrm{~s}, 1 \mathrm{H},{ }^{3} J_{\mathrm{H}-\mathrm{H}}=7.5 \mathrm{~Hz}, \mathrm{NH}_{\text {indol }}\right), 9.06\left(\mathrm{~s}, 1 \mathrm{H},{ }^{3} J_{\mathrm{H}-\mathrm{H}}=7.9 \mathrm{~Hz}, \mathrm{NH}\right), 7.61-6.98\left(\mathrm{~m}, 9 \mathrm{H}, \mathrm{H}_{\mathrm{ar}}+\mathrm{H}_{\text {indol }}\right)$, 6.30(s, $\left.1 \mathrm{H}, \mathrm{CH}_{\text {ethylenic }}\right), 4.72\left(\mathrm{ddd}, 1 \mathrm{H},{ }^{3} J_{\mathrm{H}-\mathrm{H}}=10.2 \mathrm{~Hz},{ }^{3} J_{\mathrm{H}-\mathrm{H}}=7.9 \mathrm{~Hz},{ }^{3} J_{\mathrm{H}-\mathrm{H}}=4.4 \mathrm{~Hz}{ }^{*} \mathrm{CH}-\mathrm{N}\right), 3.31(\mathrm{dd}$, $\left.1 \mathrm{H},{ }^{3} J_{\mathrm{H}-\mathrm{H}}=4.4 \mathrm{~Hz},{ }^{2} J_{\mathrm{H}-\mathrm{H}}=14.4 \mathrm{~Hz}, \mathrm{CH}_{2}\right), 3.13\left(\mathrm{dd}, 1 \mathrm{H},{ }^{3} J_{\mathrm{H}-\mathrm{H}}=10.3 \mathrm{~Hz},{ }^{2} J_{\mathrm{H}-\mathrm{H}}=14.4 \mathrm{~Hz}, \mathrm{CH}_{2}-\right.$ Indol $)$. ${ }^{13} \mathrm{C}$ NMR $\delta(\mathrm{ppm}) 100 \mathrm{MHz}, \mathrm{DMSO}-\mathrm{d}_{6}: 173.4\left(\mathrm{C}=\mathrm{O}_{\text {acid }}\right), 166.3\left(\mathrm{C}=\mathrm{O}_{\text {amide }}\right), 161.6\left(\mathrm{C}=\mathrm{O}_{\text {amide quinoline }}\right)$, $146.6\left(\mathrm{C}_{4 \mathrm{a}}-\mathrm{C}_{8 \mathrm{a}}\right), 139.5\left(\mathrm{C}_{4 \mathrm{a}}-\mathrm{C}_{8 \mathrm{a}}\right), 136.6\left(\mathrm{Cq}_{\text {ar tryptophan }}\right), 131.2\left(\mathrm{Ct}_{5}\right), 127.5\left(\mathrm{Cq}_{\text {tryptophan }}\right), 126.4\left(\mathrm{Ct}_{7}\right), 124.1$ $\left(\mathrm{Ct}_{\text {ar tryptophan }}\right), 122.3\left(\mathrm{Ct}_{\text {ar tryptophan }}\right), 121.4(=\mathrm{Ct}$ ethylenic $), 120\left(\mathrm{C}_{4}\right), 118.9\left(\mathrm{Ct}_{6}\right), 118.6\left(\mathrm{Ct}_{\text {ar tryptophan }}\right), 116.5$ $\left(\mathrm{Ct}_{\text {ar tryptophan }}\right), 116.5\left(\mathrm{Cq}_{\text {ehtylenic }}\right) 115.9\left(\mathrm{Ct}_{8}\right), 111.9\left(=\mathrm{Ct}_{\text {ethylenic tryptophan }}\right), 110.5\left(=\mathrm{Cq}_{\text {ethylenic tryptophan }}\right)$, $53.6\left({ }^{*} \mathrm{CH}-\mathrm{N}\right), 27\left(\mathrm{CH}_{2}-\right.$ Indol $)$. Mass Spectrometry: $m / z=374,1137[\mathrm{M}]^{+}, m / z=749,2292[2 \mathrm{M}+\mathrm{H}]^{+}$.

2-(6-bromo-2-oxo-1,2-dihydroquinoline-4-carboxamido)propanoic acid: 4a. White solid, $\mathrm{mp}=$ 250-252 ${ }^{\circ} \mathrm{C} .{ }^{1} \mathrm{H} \mathrm{NMR} \delta(\mathrm{ppm}) 400 \mathrm{MHz}, \mathrm{DMSO}-\mathrm{d}_{6}: 12.10\left(\mathrm{~s}, 1 \mathrm{H}, \mathrm{NH}_{\text {quinoline }}\right), 9.24\left(\mathrm{~d}, 1 \mathrm{H},{ }^{3} \mathrm{~J}_{\mathrm{H}-\mathrm{H}}=6.9 \mathrm{~Hz}\right.$, $\mathrm{NH}), 7.7-7.4\left(\mathrm{~m}, 3 \mathrm{H}, \mathrm{H}_{\mathrm{ar}}\right), 6.59\left(\mathrm{~s}, 1 \mathrm{H}, \mathrm{CH}_{\text {ethylenic }}\right), 4.50\left(\mathrm{qd}, 1 \mathrm{H},{ }^{3} \mathrm{~J}_{\mathrm{H}-\mathrm{H}}=7.2 \mathrm{~Hz},{ }^{3} \mathrm{~J}_{\mathrm{H}-\mathrm{H}}=6.9 \mathrm{~Hz},{ }^{*} \mathrm{CH}-\mathrm{N}\right)$, $1.4\left(\mathrm{~d}, 3 \mathrm{H}, \mathrm{CH}_{3}\right) .{ }^{13} \mathrm{C}$ NMR $\delta(\mathrm{ppm}) 100 \mathrm{MHz}, \mathrm{DMSO}-\mathrm{d}_{6}: 174.1\left(\mathrm{C}=\mathrm{O}_{\text {acid }}\right), 166.4\left(\mathrm{C}=\mathrm{O}_{\text {amide }}\right), 161.3$ $\left(\mathrm{C}=\mathrm{O}_{\text {amide quinoline }}\right), 144.8\left(\mathrm{C}_{4 \mathrm{a}}-\mathrm{C}_{8 \mathrm{a}}\right), 139.6\left(\mathrm{C}_{4 \mathrm{a}}-\mathrm{C}_{8 \mathrm{a}}\right), 133.9\left(\mathrm{Ct}_{5}\right), 128.4\left(\mathrm{Ct}_{7}\right), 121.6\left(=\mathrm{Ct}_{\text {ethylenic }}\right), 118.3$ $\left(\mathrm{Ct}_{4}\right), 118.2\left(\mathrm{Ct}_{8}\right), 114.3(\mathrm{Cq}), 48.5\left({ }^{*} \mathrm{CH}-\mathrm{N}\right), 16.9\left(\mathrm{CH}_{3}\right)$. Mass Spectrometry: $\mathrm{m} / z=336.9785[\mathrm{M}]^{+}$, $m / z=674.9670[2 \mathrm{M}+\mathrm{H}]^{+}$.

3-hydroxy-2-(6-bromo-2-oxo-1,2-dihydroquinoline-4-carboxamido)propanoic acid: $4 \mathrm{~b}$. White solid, $\mathrm{mp}=213-215{ }^{\circ} \mathrm{C} .{ }^{1} \mathrm{H}$ NMR $\delta(\mathrm{ppm}) 400 \mathrm{MHz}, \mathrm{DMSO}_{\mathrm{d}}$ : $11.97\left(\mathrm{~s}, 1 \mathrm{H}, \mathrm{NH}_{\text {quinoline }}\right), 9.17(\mathrm{~s}, 1 \mathrm{H}$, $\left.{ }^{3} \mathrm{~J}_{\mathrm{H}-\mathrm{H}}=6.9 \mathrm{~Hz}, \mathrm{NH}\right), 7.75-7.21\left(\mathrm{~m}, 4 \mathrm{H}, \mathrm{H}_{\mathrm{ar}}\right), 6.57\left(\mathrm{~s}, 1 \mathrm{H}, \mathrm{CH}_{\text {ethylenic }}\right), 4.5\left(\mathrm{dd}, 1 \mathrm{H},{ }^{3} J_{\mathrm{H}-\mathrm{H}}=9 \mathrm{~Hz}\right.$, $\left.{ }^{3} \mathrm{~J}_{\mathrm{H}-\mathrm{H}}=6.9 \mathrm{~Hz},{ }^{*} \mathrm{CH}-\mathrm{N}\right), 3.8\left(\mathrm{~d}, 2 \mathrm{H},{ }^{3} \mathrm{~J}_{\mathrm{H}-\mathrm{H}}=9 \mathrm{~Hz}, \mathrm{CH}_{2}-\mathrm{OH}\right) .{ }^{13} \mathrm{C}$ NMR $\delta(\mathrm{ppm}) 100 \mathrm{MHz}$, DMSO-d 6 : 173 $\left(\mathrm{C}=\mathrm{O}_{\text {acide }}\right), 166.6\left(\mathrm{C}=\mathrm{O}_{\text {amide }}\right), 161.7\left(\mathrm{C}=\mathrm{O}_{\text {amide quinoline }}\right), 146.2\left(\mathrm{C}_{4 \mathrm{a}}-\mathrm{C}_{8 \mathrm{a}}\right) 139.6\left(\mathrm{C}_{4 \mathrm{a}}-\mathrm{C}_{8 \mathrm{a}}\right), 131.3\left(\mathrm{Ct}_{5}\right), 126.4$ $\left(\mathrm{Ct}_{7}\right), 120.4\left(=\mathrm{Ct}_{\text {ethylenic }}\right), 116.6\left(\mathrm{C}_{6}\right), 116\left(\mathrm{Ct}_{4}\right), 114.4\left(\mathrm{Ct}_{8}\right), 61.3\left(\mathrm{CH}_{2}-\mathrm{O}\right), 52.6\left({ }^{*} \mathrm{CH}-\mathrm{N}\right)$. Mass Spectrometry: $\mathrm{m} / \mathrm{z}=352,9761[\mathrm{M}]^{+}$.

2-(6-bromo-2-oxo-1,2-dihydroquinoline-4-carboxamido)-2-phenylacetic acid: 4c. White solid, $\mathrm{mp}=230-232{ }^{\circ} \mathrm{C} .{ }^{1} \mathrm{H}$ NMR $\delta(\mathrm{ppm}) 400 \mathrm{MHz}, \mathrm{DMSO}-\mathrm{d}_{6}: 13.04\left(\mathrm{~s}, 1 \mathrm{H}, \mathrm{OH}_{\text {acid }}\right), 11.93(\mathrm{~s}, 1 \mathrm{H}$, $\left.\mathrm{NH}_{\text {quinoline }}\right), 9.53\left(\mathrm{~s}, 1 \mathrm{H},{ }^{3} J_{\mathrm{H}-\mathrm{H}}=5.61 \mathrm{~Hz}, \mathrm{NH}\right), 7.9-7\left(\mathrm{~m}, 9 \mathrm{H}, \mathrm{H}_{\mathrm{ar}}\right), 6.5\left(\mathrm{~s}, 1 \mathrm{H}, \mathrm{CH}_{\text {ethylenic }}\right), 5.56(\mathrm{~d}, 1 \mathrm{H}$, $\left.{ }^{3} \mathrm{~J}_{\mathrm{H}-\mathrm{H}} 5.61 \mathrm{~Hz},{ }^{*} \mathrm{CH}-\mathrm{N}\right) .{ }^{13} \mathrm{C}$ NMR $\delta(\mathrm{ppm}) 100 \mathrm{MHz}, \mathrm{DMSO}-\mathrm{d}_{6}: 172\left(\mathrm{C}=\mathrm{O}_{\text {acid }}\right), 166.7\left(\mathrm{C}=\mathrm{O}_{\text {amide }}\right), 161.2$ $\left(\mathrm{C}=\mathrm{O}_{\text {amide quinoline }}\right), 145.1\left(\mathrm{C}_{4 \mathrm{a}}-\mathrm{C}_{8 \mathrm{a}}\right), 139.6\left(\mathrm{C}_{4 \mathrm{a}}-\mathrm{C}_{8 \mathrm{a}}\right), 139\left(\mathrm{Cq}_{\mathrm{ar} \text { phenyl }}\right), 138.1\left(\mathrm{Ct}_{\mathrm{ar}}\right), 3.8\left(\mathrm{Ct}_{5}\right), 129.5\left(\mathrm{Ct}_{7}\right)$, $128.7\left(\mathrm{Ct}_{\text {ar phenyl }}\right), 128.6\left(\mathrm{Ct}_{\text {ar phenyl }}\right), 127\left(\mathrm{Ct}_{7}\right), 121.30\left(=\mathrm{Ct}_{\text {ethylenic }}\right), 116.2\left(\mathrm{Cq}_{4}\right), 116\left(\mathrm{Ct}_{8}\right), 57.6\left({ }^{*} \mathrm{CH}-\mathrm{N}\right)$. Mass Spectrometry: $m / z=398,9975[\mathrm{M}]^{+}, m / z=799,0034[2 \mathrm{M}+\mathrm{H}]^{+}$.

2-(6-bromo2-oxo-1,2-dihydroquinoline-4-carboxamido)-3-phenylpropanoic acid: 4d. White solid, $\mathrm{mp}=240-242{ }^{\circ} \mathrm{C} .{ }^{1} \mathrm{H}$ NMR $\delta(\mathrm{ppm}) 400 \mathrm{MHz}, \mathrm{DMSO}-\mathrm{d}_{6}: 13.03\left(\mathrm{~s}, 1 \mathrm{H}, \mathrm{OH}_{\mathrm{acid}}\right), 12.08(\mathrm{~s}, 1 \mathrm{H}$, $\left.\mathrm{NH}_{\text {quinoline }}\right), 9.17\left(\mathrm{~s}, 1 \mathrm{H},{ }^{3} J_{\mathrm{H}-\mathrm{H}}=5.61 \mathrm{~Hz}, \mathrm{NH}\right), 7.9-7\left(\mathrm{~m}, 9 \mathrm{H}, \mathrm{H}_{\mathrm{ar}}\right), 6.32\left(\mathrm{~s}, 1 \mathrm{H}, \mathrm{CH}_{\text {ethylenic }}\right), 4.69$ (d, $\left.1 \mathrm{H},{ }^{3} J_{\mathrm{H}-\mathrm{H}}=5.61 \mathrm{~Hz},{ }^{*} \mathrm{CH}-\mathrm{N}\right), 3.25\left(\mathrm{dd}, 1 \mathrm{H},{ }^{3} J_{\mathrm{H}-\mathrm{H}}=4.8 \mathrm{~Hz},{ }^{2} J_{\mathrm{H}-\mathrm{H}}=13.8 \mathrm{~Hz}, \mathrm{CH}_{2}-\mathrm{Ar}\right), 2.95(\mathrm{dd}, 1 \mathrm{H}$, 
$\left.{ }^{3} J_{\mathrm{H}-\mathrm{H}}=11.1 \mathrm{~Hz},{ }^{2} J_{\mathrm{H}-\mathrm{H}}=13.8 \mathrm{~Hz}, \mathrm{CH}_{2}-\mathrm{Ar}\right) .{ }^{13} \mathrm{C} \mathrm{NMR} \delta(\mathrm{ppm}) 100 \mathrm{MHz}, \mathrm{DMSO}-\mathrm{d}_{6}: 173\left(\mathrm{C}=\mathrm{O}_{\text {acid }}\right)$, $165.7\left(\mathrm{C}=\mathrm{O}_{\text {amide }}\right), 161.2\left(\mathrm{C}=\mathrm{O}_{\text {amide quinoline }}\right), 145\left(\mathrm{C}_{4 \mathrm{a}}-\mathrm{C}_{8 \mathrm{a}}\right), 138.7\left(\mathrm{C}_{4 \mathrm{a}}-\mathrm{C}_{8 \mathrm{a}}\right), 138.1\left(\mathrm{Cq}_{\text {ar phenyl }}\right), 134\left(\mathrm{Ct}_{5}\right)$, $129.5\left(\mathrm{Ct}_{7}\right), 128.6\left(=\mathrm{Ct}_{\text {ethylenic }}\right), 128.3\left(\mathrm{Ct}_{\text {ar phenyl }}\right), 127\left(\mathrm{Ct}_{4}\right), 121.3\left(=\mathrm{Ct}_{\text {ethylenic }}\right), 118.2\left(\mathrm{C}_{6}\right), 118.0$ $(\mathrm{Cq}$ phenyl $), 114.2\left(\mathrm{Ct}_{8}\right), 53.9\left(\mathrm{CH}_{2}-\mathrm{Ar}\right), 54\left({ }^{*} \mathrm{CH}-\mathrm{N}\right), 36.7\left(\mathrm{CH}_{2}\right)$. Mass Spectrometry: $\mathrm{m} / z=413,0124$ $[\mathrm{M}]^{+}, m / z=827,0356[2 \mathrm{M}+\mathrm{H}]^{+}$.

2-(6-bromo-2-oxo-1,2-dihydroquinoline-4-carboxamido)-3-phenylpropanoic acid: 4e. White solid. $\mathrm{Mp}=260-262{ }^{\circ} \mathrm{C} .{ }^{1} \mathrm{H}$ NMR $\delta(\mathrm{ppm}) 400 \mathrm{MHz}, \mathrm{DMSO}-\mathrm{d}_{6}: 12.98\left(\mathrm{~s}, 1 \mathrm{H}, \mathrm{OH}_{\mathrm{acid}}\right), 12.22(\mathrm{~s}, 1 \mathrm{H}$, $\left.\mathrm{NH}_{\text {quinoline }}\right), 10.88\left(\mathrm{~s}, 1 \mathrm{H},{ }^{3} J_{\mathrm{H}-\mathrm{H}}=7.5 \mathrm{~Hz}, \mathrm{NH}_{\text {indol }}\right), 9.15\left(\mathrm{~s}, 1 \mathrm{H},{ }^{3} J_{\mathrm{H}-\mathrm{H}}=7.9 \mathrm{~Hz}, \mathrm{NH}\right), 8.43(\mathrm{~d}$, $\left.1 \mathrm{H},{ }^{4} J_{\mathrm{H}-\mathrm{H}}=2.2 \mathrm{~Hz}, \mathrm{H}_{\mathrm{ar}}\right), 7.61-6.98\left(\mathrm{~m}, 8 \mathrm{H}, \mathrm{H}_{\mathrm{ar}}+\mathrm{H}_{\text {indol }}\right), 6.37\left(\mathrm{~s}, 1 \mathrm{H}, \mathrm{CH}_{\text {ethylenic }}\right), 4.67$ (ddd, $1 \mathrm{H}$, $\left.{ }^{3} J_{\mathrm{H}-\mathrm{H}}=10.2 \mathrm{~Hz},{ }^{3} J_{\mathrm{H}-\mathrm{H}}=7.9 \mathrm{~Hz},{ }^{3} J_{\mathrm{H}-\mathrm{H}}=4.4 \mathrm{~Hz}{ }^{*} \mathrm{CH}-\mathrm{N}\right), 3.31\left(\mathrm{dd}, 1 \mathrm{H},{ }^{3} J_{\mathrm{H}-\mathrm{H}}=4.4 \mathrm{~Hz},{ }^{2} J_{\mathrm{H}-\mathrm{H}}=14.4 \mathrm{~Hz}\right.$, $\mathrm{CH}_{2}$-Indo), $3.14\left(\mathrm{dd}, 1 \mathrm{H},{ }^{3} J_{\mathrm{H}-\mathrm{H}}=10.3 \mathrm{~Hz},{ }^{2} J_{\mathrm{H}-\mathrm{H}}=14.4 \mathrm{~Hz}, \mathrm{CH}_{2}\right.$-Indol $) .{ }^{13} \mathrm{C}$ NMR $\delta(\mathrm{ppm}) 100$ MHz, DMSO- $\mathrm{d}_{6}: 173.4\left(\mathrm{C}=\mathrm{O}_{\text {acid }}\right), 166.7\left(\mathrm{C}=\mathrm{O}_{\text {amide }}\right), 161.6\left(\mathrm{C}=\mathrm{O}_{\text {amide quinoline }}\right), 146.3\left(\mathrm{C}_{4 \mathrm{a}}-\mathrm{C}_{8 \mathrm{a}}\right), 138.6$ $\left(\mathrm{C}_{4 \mathrm{a}}-\mathrm{C}_{8 \mathrm{a}}\right), 136.6\left(\mathrm{Cq}_{\text {ar tryptophan }}\right), 133.8\left(\mathrm{Ct}_{5}\right), 127.56\left(\mathrm{Cq}_{\text {tryptophan }}\right), 125.99\left(\mathrm{Ct}_{7}\right), 124.1\left(\mathrm{Ct}_{\text {ar tryptophan }}\right)$, $121.4\left(=\mathrm{Ct}_{\text {ethylenic }}\right), 118.8\left(\mathrm{Ct}_{\text {ar tryptophan }}\right), 118.5\left(\mathrm{C}_{4}\right), 118.3\left(\mathrm{Ct}_{\text {ar tryptophan }}\right), 118.1\left(\mathrm{Ct}_{\text {ar tryptophan }}\right), 117.9$ $(\mathrm{Cq}$ ehtylenic $) 114.5\left(\mathrm{Ct}_{8}\right), 111.9$ (=Ct $\left.\mathrm{t}_{\text {ethylenic tryptophan }}\right), 110.5$ (=Cq $\left.\mathrm{Cq}_{\text {ethylenic tryptophan }}\right), 53.9\left({ }^{*} \mathrm{CH}-\mathrm{N}\right), 26.9$ $\left(\mathrm{CH}_{2}\right.$-Indol $)$. Mass Spectrometry: $m / z=452,0241[\mathrm{M}]^{+}, m / z=905,0624[2 \mathrm{M}+\mathrm{H}]^{+}$.

Antibacterial assay-minimum inhibitory concentration (MIC). The MICs of the amino ester derivatives 1a-2e and the amino acid derivatives 3a-4e were determined by the broth microdilution method [31]. A 96-well polypropylene microliter plate was filled with $50 \mu \mathrm{L}$ of Mueller-Hinton broth (MHB). Then, $50 \mu \mathrm{L}$ of each sample at a final concentration of $10 \mathrm{mg} / \mathrm{mL}$ was added into the first well. Serial $\frac{1}{2}$ dilutions were realized by pipetting $50 \mu \mathrm{L}$ from the first well and transferred to the next one. This operation was repeated until the 12 th well and the last $50 \mu \mathrm{L}$ mixture was discarded. Finally, a volume of $50 \mu \mathrm{L}$ of bacterial suspension was added into each well at a final concentration of approximately $106 \mathrm{CFU} / \mathrm{mL}$. The 96-well plate was then covered and was incubated at $37^{\circ} \mathrm{C}$ for $24 \mathrm{~h}$. After that, $5 \mu \mathrm{L}$ of resazurin was pipetted into all the wells and incubated another time at $37^{\circ} \mathrm{C}$ for $2 \mathrm{~h}$. The MIC was presented as the lowest concentration that showed a negative bacterial growth translated by a non-change in resazurin color. A positive one is detected by reduction of the blue dye resazurin to pink resorufin [32].

Fluorometry: The fluorescence spectra of all the solutions were measured at room temperature using a Shimadzu RF-5001-Pc spectrofluorometer and were investigated in DMSO at concentration of $10 \mathrm{mg} / \mathrm{mL}$ (DMSO).

\subsection{Computational Methods}

Prediction of putative bacterial targets: Since our new compounds resemble structurally aminocoumarins and quinolones, we chose DNA gyrase/topoisomerase IV as the putative bacterial target proteins. In addition, we used the similarity ensemble approach (SEA) server (http: //sea.bkslab.org; [33] to search for possible bacterial targets using the 2-oxo-1,2-dihydroquinoline basic scaffold with a methyl group or an amide at position 4 .

Identification of putative binding sites at DNA gyrase: To map the possible binding sites in topoisomerase type II enzymes, we investigated the available sequence and structural data of bacterial DNA gyrases. The DNA gyrase subunit A (GyrA) and subunit B (GyrB) sequences of E. coli, P. aeruginosa, S. aureus and B. subtilis were retrieved from the UniProt database [34] and aligned using the Clustal Omega multiple sequence alignment tool [35]. There are many experimental structures of E. coli and $S$. aureus DNA gyrase in complex with various inhibitors available in the Protein Data Bank (PDB) [36]. In addition, very recently two crystal structures of $P$. aeruginosa ATP-binding domain in complex with pyrido[2,3-b]indole derivatives were reported (PDB IDs 6M1S and 6M1J [37]. We selected representative crystal complexes of DNA gyrases (and one topoisomerase IV) and identified the ligand-interacting residues in them to gain an idea about the key interactions at each binding site (GyrA: fluoroquinolone binding site (PDB ID: 2XCT); simocyclinone D8 binding site (PDB ID: 2Y3P [38]); NBTI binding site (PDB IDs: 5BS3 [39], 4PLB [40], 6QTP [41], 6RKW [42]); GyrB: ATP-/coumarin binding site (PDB IDs: 
4PRX [43], 1AJ6 [44], 6ENG [45], 5CPH [46], 3TTZ [47], 6RKW, 4DUH [48]); topoisomerase IV Par E subunit: ATP-/coumarin binding site (PDB ID: 1S14 [49]).

Ligand and protein preparation: The 2D molecular structures of the synthesized compounds 3a-4e were initially prepared using ChemDraw Version 19.1 and then imported to the Maestro molecular modelling suite (Release 2020-2: Schrödinger, LLC, New York, NY, 2020). The LigPrep tool of Maestro (Schrödinger Release 2020-2) was used to generate optimized low-energy 3D conformers of the ligands in the OPLS3e force field [50]. Possible tautomeric states for each ligand were generated at $\mathrm{pH}$ of $7.0 \pm 2.0$ with Epik [51,52]. The Protein Preparation Wizard [53] of Maestro was used for preparing the selected target structures: S. aureus DNA gyrase (GyrA) in complex with ciprofloxacin (PDB ID: 2XCT, resolution $3.35 \AA$ ) and with "compound 7" (NBTI) (PDB ID: 5BS3, resolution 2.65 A); a 24-kDa domain of E. coli topoisomerase IV ParE subunit in complex with novobiocin (PDB ID: 1S14, resolution $2.00 \AA$ ) and a $24-\mathrm{kDa}$ domain of GyrB subunit of E. coli DNA gyrase in complex with a 4,5'-bithiazole inhibitor ("inhibitor 18" according to the authors in [48]; PDB ID: 4DUH, resolution $1.50 \AA$ ). The missing hydrogen atoms were added and the hydrogen bond network was optimized with PROPKA at pH 7.0. Moreover, all water molecules beyond $3 \AA$ were removed and a restrained minimization was carried out using the OPLS3e force field with a convergence criterion of 0.3- $\AA$ root-mean-square deviation (RMSD) for all heavy atoms.

Docking protocol: Based on the initial analysis of the putative binding sites in bacterial DNA gyrases, three distinct sites were used for the docking studies: two sites in GyrA (fluroquinolone and NBTI binding sites) and coumarin binding site in GyrB. For comparison, the coumarin binding site at topoisomerase IV ParE subunit was also used for docking. The receptor grid generation tool of the docking program Glide [54-56] in Maestro was employed to define the docking site at each target protein around the coordinates of the respective co-crystallised ligands. The van der Waals scaling factor was set to 0.80 with a partial charge cut-off of 0.25 . The outer box size of the docking grid was set to $30 \AA \times 30 \AA \times 30 \AA$ (the diameter midpoint of the docked ligands was set to remain in an inner box with dimensions of $10 \AA \times 10 \AA \times 10 \AA$ and the size of the ligands to be docked was set to $\leq 20 \AA$ ). The docking was carried out using both the Glide standard precision (SP) and extra precision (XP) modes with flexible ligand sampling. The Epik state penalties were added to the final docking scores. For each ligand, five or ten poses were taken for post-docking minimization in SP and XP mode, respectively. Maximum of five poses were generated per ligand. The docking protocol was validated by redocking the co-crystallized compounds back to their respective crystal positions.

Binding free energy estimation: The docked poses were then re-ranked using the Prime $[57,58]$ MM-GBSA binding energy values calculated in the OPLS3e force field. The Prime/MM-GBSA analysis employs the variable dielectric generalized Born solvation model (VSGB 2.1) [59] and predicts the free energy of binding for protein-ligand complexes. The binding free energy $\Delta \mathrm{G}_{\mathrm{bind}}$ was calculated using the following equation:

$$
\Delta \mathrm{G}_{\text {bind }}=\mathrm{G}_{\text {complex }}-\left(\mathrm{G}_{\text {receptor }}+\mathrm{G}_{\text {ligand }}\right)
$$

where $G_{\text {complex }}$ is the free energy of the protein-ligand complex, $G_{\text {receptor }}$ is the free energy of the protein and $G_{\text {ligand }}$ is the free energy of the ligand. These energy values are calculated as:

$$
\mathrm{G}=\mathrm{G}_{\mathrm{MM}}+\mathrm{G}_{\mathrm{Solv}}
$$

where $G_{M M}$ is the calculated molecular mechanics energy for the force field applied, and $G_{\text {solv }}$ is the solvation energy in the generalized Born approximation. For comparison, the Prime/MM-GBSA binding free energies were also computed for the co-crystallized ligands in the target sites.

Molecular dynamics (MD) simulation analysis: The most promising ligand-protein complexes with high predicted docking scores and/or binding free energies were each subjected to a short 10-ns molecular dynamics (MD) simulation with Desmond (Schrödinger Release 2020-2: Desmond Molecular Dynamics System, D. E. Shaw Research, New York, NY, USA, 2020. Maestro-Desmond Interoperability Tools, Schrödinger, New York, NY, USA, 2020) [60] to refine the docked poses and evaluate the stability 
of binding at the target sites. For comparison, the native crystal complexes of the studied targets were also simulated using the same protocol. The simulation systems were prepared with the System Builder tool of Desmond module as implemented in Maestro. The single point charge (SPC) water [61] was chosen as the solvation model and each system was neutralized using an appropriate number of Na+ counterions. An orthorhombic simulation box with Periodic Boundary Conditions (PBC) and a 10- $\AA$ buffer space between the solute and the box edge was used. The simulation systems were equilibrated before the actual simulations (see the detailed protocol in Supplementary Material). After the system relaxation, a production simulation in the NPT ensemble was run for $10 \mathrm{~ns}$ using a 2-fs time step. The temperature ( $300 \mathrm{~K})$ was set with the Nosé-Hoover chain thermostat [62-64] using a relaxation time of $1.0 \mathrm{ps}$, and the pressure was set at 1.01325 bar with the Martyna-Tobias-Klein barostat [65] using isotropic coupling and relaxation time of $2.0 \mathrm{ps.} \mathrm{For} \mathrm{handling} \mathrm{the} \mathrm{short-range}$ Coulombic interactions, a cut-off radius of $9.0 \AA$ was used. The MD trajectories were analysed using the Maestro in-built Simulation Interactions Diagram tool and Microsoft Excel360. The Prime/MM-GBSA energies were calculated for the whole trajectories (from thousand snapshot structures every 10th was used as an input for the script).

\section{Results and Discussion}

\subsection{Synthesis of Quinoline Amino Acids Derivatives}

Recently, Moussaoui et al. [66] reported a new series of 2-oxo-1,2-dihydroquinoline carboxamides 1a-e and 2a-2e based on amino acid methyl esters and studied their antibacterial activity. As a continuation study, we synthesized ten new structures of amino acid derivatives of quinolines following a three-step reaction (Scheme 1).

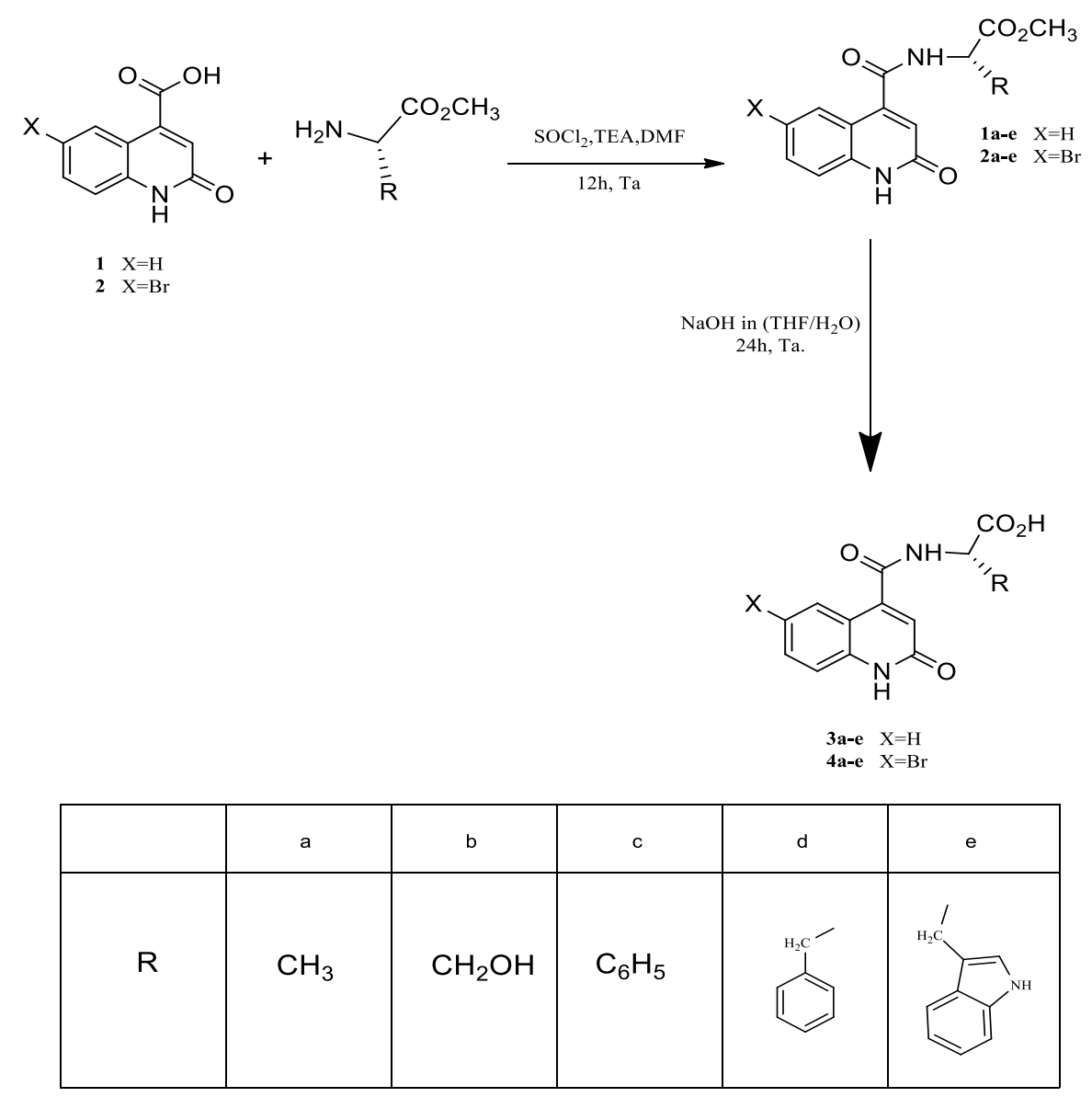

Scheme 1. Synthesis of quinoline amino acids 3a-e and $4 a-e$. 
First, substrates 1 and 2 were prepared under reflux conditions for $24 \mathrm{~h}$ by reacting both isatin and its bromo-derivatives with malonic acid in the presence of sodium acetate in acetic acid. Then, the compounds $\mathbf{1 a - e}$ and $\mathbf{2 a - e}$ were synthesized by coupling $\mathbf{1}$ and $\mathbf{2}$ with five different amino acid esters (L-alanine-OMe, L-serine-OMe, L-phenylalanine-OMe, L-phenylglycine-OMe and L-tryptophan-OMe) for $12 \mathrm{~h}$ at room temperature in basic conditions using triethylamine (TEA) in the presence of thionyl chloride $\left(\mathrm{SOCl}_{2}\right)$ as a coupling agent and dimethylformamide (DMF) as a solvent. During the last reaction step, the esters were converted to the corresponding acids 3a-e and 4a-e (Figure 1) by the hydrolysis with sodium hydroxide in the presence of a mixture of tetrahydrofuran (THF)/water $(1 / 2 ; v / v)$ for $24 \mathrm{~h}$ at room temperature. The progress of reaction was monitored by thin layer chromatography (TLC). All newly synthesized compounds were purified by column chromatography using silica gel as the stationary phase. The final yield of the compounds was 80-90\% (Figure 1). In all cases, the yields presented are the isolated yields after purification.<smiles>CC(NC(=O)c1cc(=O)[nH]c2ccccc12)C(=O)O</smiles>

3a $90 \%$<smiles>O=C(NC(CO)C(=O)O)c1cc(=O)[nH]c2ccccc12</smiles>

3b $80 \%$<smiles>O=C(NC(C(=O)O)c1ccccc1)c1cc(=O)[nH]c2ccccc12</smiles>

3c $85 \%$<smiles>O=C(NC(Cc1ccccc1)C(=O)O)c1cc(=O)[nH]c2ccccc12</smiles>

3d 88\%<smiles>O=C(NC(CC1=CNC2C=CC=CC12)C(=O)O)c1cc(=O)[nH]c2ccccc12</smiles>

3e $90 \%$<smiles>CC(NC(=O)c1cc(=O)[nH]c2ccc(Br)cc12)C(=O)O</smiles><smiles>O=C(N[C@@H](CO)C(=O)O)c1cc(=O)[nH]c2ccc(Br)cc12</smiles><smiles>O=C(NC(C(=O)O)c1ccccc1)c1cc(=O)[nH]c2ccc(Br)cc12</smiles>

4a $88 \%$

4b $82 \%$<smiles>O=C(NC(Cc1ccccc1)C(=O)O)c1cc(=O)[nH]c2ccc(Br)cc12</smiles>

4d $90 \%$<smiles>O=C(N[C@@H](CC1=CNC2C=CC=CC12)C(=O)O)c1cc(=O)[nH]c2ccc(Br)cc12</smiles>

4 e $90 \%$

Figure 1. Structures and yields (\%) of the synthesized amino acid derivatives of quinolines $3 a-3 e$ and $4 a-4 e$.

\subsection{Characterisation of the Synthesized Compounds}

The chemical structures of all newly synthesized molecules were characterized by ${ }^{1} \mathrm{H},{ }^{13} \mathrm{C}$ NMR spectroscopy and ESI-TOF mass-spectrometry. The characteristic ${ }^{1} \mathrm{H}$ NMR signals of quinoline carboxamide derivatives $3 \mathbf{a}-\mathbf{e}$ and $\mathbf{4 a - e}$ displayed the absence of methoxy protons $-\mathrm{OCH}_{3}$. In addition, the presence of a large (important) signal correlated to the proton in $\mathrm{OH}$ of the acid, confirming the formation of the carboxylic acid $-\mathrm{COOH}$ functional group (Table 1). The ${ }^{1} \mathrm{H}$ NMR spectrum of the compound 3a shows a doublet at $\delta=1.4 \mathrm{ppm}$, corresponding to the $\mathrm{CH}_{3}$ group coupled with the proton of the asymmetric carbon ${ }^{*} \mathrm{CH}$. The signal of this later appears at $\delta=4.8 \mathrm{ppm}$ as a doublet of 
a quadruplet with both corresponding coupling constants ${ }^{3} J=7.5 \mathrm{~Hz}$ and ${ }^{3} J=7.2 \mathrm{~Hz}$. In addition, a signal at $\delta=6.5 \mathrm{ppm}$ concerns the intracyclic ethylenic proton of quinoline. The proton of $\mathrm{NH}$ amide function is illustrated by the presence of a doublet at $\delta=9 \mathrm{ppm}$ with a coupling constant ${ }^{3} \mathrm{~J}=7.5 \mathrm{~Hz}$. Hence, the singlet at $\delta=12 \mathrm{ppm}$ refers to the $\mathrm{NH}$ proton of quinoline. The spectral region between $\delta=7.2-7.93 \mathrm{ppm}$ is assigned to both aromatic protons. A large unstable signal between $\delta=3-4 \mathrm{ppm}$ is assigned to the proton in $\mathrm{OH}$ of the acid function. The ${ }^{13} \mathrm{C}$ NMR spectrum of $3 \mathbf{a}$ exhibited a quaternary signal at $\delta=174 \mathrm{ppm}, \delta=166.27 \mathrm{ppm}$ and $\delta=161.73 \mathrm{ppm}$ due to the carbonyl carbon of amide, the acid function, and the amide in the quinoline ring, respectively. The signals between $\delta=146.53-116.08 \mathrm{ppm}$ are assigned to aromatic carbons, while a signal at $\delta=48.32 \mathrm{ppm}$ shows the presence of the asymmetric carbon ${ }^{*} \mathrm{CH}$ and a shielded signal at $\delta=17.07 \mathrm{ppm}$ corresponds to the methylene carbon $\mathrm{CH}_{3}$.

Table 1. Proton NMR ${ }^{1} \mathrm{H} \delta$ (ppm) and carbon ${ }^{13} \mathrm{C}$ NMR $\delta$ (ppm) shifts of acid function.

\begin{tabular}{|c|c|c|}
\hline Compound & NMR ${ }^{1} \mathrm{H}$ (ppm) & $\mathrm{NMR}{ }^{13} \mathrm{C}(\mathrm{ppm})$ \\
\hline $3 a$ & $\begin{array}{c}3-4 \\
\text { Unstable with signal of } \mathrm{H}_{2} \mathrm{O}\end{array}$ & 174.2 \\
\hline $3 b$ & $\begin{array}{c}3-4 \\
\text { Unstable with signal of } \mathrm{H}_{2} \mathrm{O}\end{array}$ & 173.1 \\
\hline $3 c$ & 13.04 & 172.0 \\
\hline $3 d$ & $\begin{array}{c}3-4 \\
\text { Unstable with signal of } \mathrm{H}_{2} \mathrm{O}\end{array}$ & 173.2 \\
\hline $3 e$ & 13.00 & 173.4 \\
\hline $4 a$ & $\begin{array}{l}\quad 3-4 \\
\text { Unstable with signal of } \mathrm{H}_{2} \mathrm{O}\end{array}$ & 173.0 \\
\hline $4 b$ & $\begin{array}{c}3-4 \\
\text { Unstable with signal of } \mathrm{H}_{2} \mathrm{O}\end{array}$ & 173.0 \\
\hline $4 c$ & 13.03 & 172.0 \\
\hline $4 d$ & 13.03 & 173.0 \\
\hline $4 e$ & 12.98 & 173.4 \\
\hline
\end{tabular}

ESI-TOF mass spectrum of compound 3a showed $[\mathrm{M}]^{+}$peak at $\mathrm{m} / \mathrm{z}=260.1086$, which is in agreement with its molecular formula $\mathrm{C}_{13} \mathrm{H}_{11} \mathrm{~N}_{2} \mathrm{O}_{4}$. The results of compound characterization for the rest of the synthesized amino acid derivatives are presented in the experimental part.

\subsection{Antibacterial Activity}

The antibacterial activity of all the synthesized compounds (both the amino acid ester derivatives $\mathbf{1 a}-\mathbf{e}$ and $\mathbf{2 a}-\mathbf{e}$ as well as the amino acid derivatives of quinolines $\mathbf{3 a} \mathbf{a}-\mathbf{e}$ and $\mathbf{4 a - e}$ ) was tested against four different bacterial strains: Escherichia coli ATCC 25922, Staphylococcus aureus ATCC 29213, Pseudomonas aeruginosa ATCC 27853 and Bacillus subtilis ATCC 3366. The screening was performed using a quantitative method that determines the minimum inhibitory concentration (MIC).

The results from the antibacterial activity screening are presented in Table 2. Most of the amino ester quinolines displayed only a very weak or no antibacterial effect. Compounds $\mathbf{1 a}$ and $\mathbf{1} \mathbf{b}$ had the lowest MIC values of $2.5 \mathrm{mg} / \mathrm{mL}$ and $5 \mathrm{mg} / \mathrm{mL}$ against $B$. subtilis, whereas compounds $\mathbf{2 a}, \mathbf{2 b}, \mathbf{2} \mathbf{c}$ and $\mathbf{2 e}$ did not show any activity against any of the tested bacterial strains. Compounds $\mathbf{1 a}, \mathbf{1 c}, \mathbf{1 d}$ and 1e showed only a relatively weak activity against $P$. aeruginosa with MICs of $10.0 \mathrm{mg} / \mathrm{mL}$. Likewise, compounds $\mathbf{1 a}$ and $\mathbf{2 d}$ inhibited S. aureus and compound $\mathbf{1 e}$ inhibited B. subtilis with only similarly high MICs of $10.0 \mathrm{mg} / \mathrm{mL}$. 
Table 2. In vitro antibacterial activities (minimum inhibitory concentration (MIC) values in $\mathrm{mg} / \mathrm{mL}$ ) of amino acid ester quinolines $\mathbf{1} \mathbf{a}-\mathbf{e}$ and $\mathbf{2 a}-\mathbf{e}$ and amino acid quinolines $\mathbf{3 a - e}$ and $\mathbf{4 a - e}$ against Gram-negative (Escherichia coli (E. coli) and Pseudomonas aeruginosa (P. aeruginosa)) and Gram-positive (Staphylococcus aureus (S. aureus) and Bacillus subtilis (B. subtilis)) bacterial strains.

\begin{tabular}{|c|c|c|c|c|}
\hline Compound & $\begin{array}{c}\text { Staphylococcus } \\
\text { aureus ATCC } 29213\end{array}$ & $\begin{array}{c}\text { Pseudomonas } \\
\text { aeruginosa ATCC } 27853\end{array}$ & $\begin{array}{c}\text { Bacillus subtilis } \\
\text { ATCC } 3366\end{array}$ & $\begin{array}{l}\text { Escherichia coli } \\
\text { ATCC } 25922\end{array}$ \\
\hline 1a & 10.0 & 10.0 & 2.5 & NA \\
\hline $1 b$ & NA & NA & 5.0 & 10 \\
\hline 1c & NA & 10.0 & NA & NA \\
\hline $1 d$ & NA & 10.0 & NA & NA \\
\hline $1 \mathrm{e}$ & NA & 10.0 & 10.0 & NA \\
\hline $2 a$ & NA & NA & NA & NA \\
\hline $2 b$ & NA & NA & NA & NA \\
\hline $2 c$ & NA & NA & NA & NA \\
\hline $2 d$ & 10.0 & 2.5 & 2.5 & NA \\
\hline $2 \mathrm{e}$ & NA & NA & NA & NA \\
\hline $3 a$ & 0.62 & 0.62 & 0.62 & 0.62 \\
\hline $3 b$ & 2.5 & 2.5 & 2.5 & 1.25 \\
\hline $3 c$ & 2.5 & 2.5 & 2.5 & 1.25 \\
\hline $3 d$ & 5.0 & 2.5 & 1.25 & 1.25 \\
\hline $3 e$ & 0.31 & 2.5 & 2.5 & 2.5 \\
\hline $4 a$ & 5.0 & 1.25 & 2.5 & 1.25 \\
\hline $4 b$ & 1.25 & 2.5 & 1.25 & 2.5 \\
\hline $4 c$ & 5 & 1.25 & 2.5 & 1.25 \\
\hline $4 \mathrm{~d}$ & 5 & 1.25 & 2.5 & 1.25 \\
\hline $4 e$ & 0.62 & 2.5 & 2.5 & 1.25 \\
\hline
\end{tabular}

NA: No Activity.

On the other hand, most of the new amino acid derivatives of quinolines were more potent antibacterial agents than their ester counterparts. Compound 3 a revealed an equipotent antimicrobial activity against all tested bacteria with a moderate MIC of $0.62 \mathrm{mg} / \mathrm{mL}$. Thus, it could be considered as a promising antibacterial hit compound. The corresponding bromine-substituted compound 4a showed a somewhat reduced antibacterial activity and it also inhibited Gram-negative and Gram-positive bacteria differently. It had a relatively weak activity against Gram-negative bacteria (E. coli and $P$. aeruginosa) with a MIC of $1.25 \mathrm{mg} / \mathrm{mL}$ but was even less active against Gram-positive bacteria (MIC $=2.5 \mathrm{mg} / \mathrm{mL}$ and MIC $=5.0 \mathrm{mg} / \mathrm{mL}$ for B. subtilis and S. aureus, respectively).

Compounds $\mathbf{3 b}$ and $\mathbf{3} \mathbf{c}$ were only modest inhibitors of $E$. coli $(\mathrm{MIC}=1.25 \mathrm{mg} / \mathrm{mL}$ ) and showed even less activity against the other bacteria (MIC $=2.5 \mathrm{mg} / \mathrm{mL}$ ). In the case of $4 \mathbf{b}$, the bromine function made it somewhat more potent against Gram-positive bacteria with a MIC of $1.25 \mathrm{mg} / \mathrm{mL}$ but reduced its activity against $E$. coli (MIC $=2.5 \mathrm{mg} / \mathrm{mL}$ ). Compared to $3 \mathrm{c}$, compound $4 \mathrm{c}$ has a slightly stronger inhibitory effect against $P$. aeruginosa with a MIC of $1.25 \mathrm{mg} / \mathrm{mL}$ but a significantly reduced effect against $S$. aureus with a MIC of only $5.0 \mathrm{mg} / \mathrm{mL}$. On the other hand, we can see that the bromination of 3d modified positively the antibacterial activity against $P$. aeruginosa from a MIC of $2.5 \mathrm{mg} / \mathrm{mL}$ to a MIC of $1.25 \mathrm{mg} / \mathrm{mL}$ but somewhat reduced the activity against B. subtilis. The tryptophan derivatives 3e and 4e displayed a moderate inhibitory activity against $S$. aureus with a MIC of $0.31 \mathrm{mg} / \mathrm{mL}$ and $0.62 \mathrm{mg} / \mathrm{mL}$, respectively. Bromination increased the activity against $E$. coli (from MIC $=2.5 \mathrm{mg} / \mathrm{mL}$ to MIC $=1.25 \mathrm{mg} / \mathrm{mL}$ ), whereas there was no change in the activity against P. aeruginosa or B. subtilis $(\mathrm{MIC}=2.5 \mathrm{mg} / \mathrm{mL})$.

In sum, the results obtained show that the antimicrobial activity of quinolone carboxamides increases after the hydrolysis of the amino acid ester moiety. It is observed that the nature of the amino acid and the substitution at the quinoline moiety influence the structure-activity relationship of these compounds. However, the activities of the studied acid derivatives are still weak $(1.25-2.5 \mathrm{mg} / \mathrm{mL})$ or at best moderate $(0.31-0.62 \mathrm{mg} / \mathrm{mL})$. 


\subsection{Fluorometry}

The fluorescent properties of the synthesized compounds were measured in DMSO at room temperature. In general, all compounds tested have relatively high values of $\varepsilon$ (the molar extinction/absorption coefficient at the excitation wavelength), which makes them potentially interesting as new fluorophore structures that are stable over long periods of time. Interestingly, we observed that the $\varepsilon$ values of compounds $4 \mathbf{d}$ and $4 \mathbf{e}$ were significantly higher than those of the other compounds $\left(\varepsilon=10,100 \mathrm{M}^{-1} \mathrm{~cm}^{-1}\right.$ at $382 \mathrm{~nm}$ and $\varepsilon=10,130 \mathrm{M}^{-1} \mathrm{~cm}^{-1}$ at $394 \mathrm{~nm}$, respectively). This is likely due to the presence of an additional aromatic ring and the Br substituent which can contribute to the delocalization of electrons and therefore can absorb light energy (excitation light) and restore it in the form of fluorescent light (emission light).

The emission spectra of the synthesized compounds were observed in the violet region $\left(380 \mathrm{~nm}<\lambda_{\mathrm{em}}<450 \mathrm{~nm}\right)$ While the minimum fluorescence emission was observed for $3 \mathbf{e}\left(\lambda_{\mathrm{em}}=412 \mathrm{~nm}\right)$, the maximum was observed at $\lambda_{\mathrm{em}}=439 \mathrm{~nm}$ for $3 \mathbf{a}$ (Table 3). The Stokes shift (the difference between the maximum wavelengths of excitation and emission in nanometers) that affects the sensitivity of fluorescence detection varied between $41 \mathrm{~nm}$ and $63 \mathrm{~nm}$ among the synthesized compounds. The highest shift value was assigned to compound $3 \mathbf{a}$ (Table 3 ).

Table 3. Fluorescence data for the synthesized compounds 3a, 3c, 3d, 3e, $4 \mathbf{d}$ and $4 \mathbf{e}$.

\begin{tabular}{ccccccc}
\hline Compound & $\mathbf{U V}\left(\boldsymbol{\lambda}_{\max }\right)$ & $\boldsymbol{\varepsilon}\left(\mathbf{M}^{-\mathbf{1}} \mathbf{c m}^{\mathbf{- 1}}\right)$ & $\boldsymbol{\lambda}_{\mathbf{e x c}}$ & $\boldsymbol{\lambda}_{\mathbf{e m}}$ & Stokes Shift $(\mathbf{n m})$ & $\boldsymbol{\Phi}_{\mathbf{I}}$ \\
\hline 3a & 390 & 9440 & 376 & 439 & 63 & 0.151 \\
3c & 371 & 8530 & 374 & 431 & 57 & 0.179 \\
3d & 392 & 9980 & 371 & 412 & 41 & 0.071 \\
3e & 372 & 9900 & 379 & 422 & 43 & 0.100 \\
4d & 382 & 10,100 & 377 & 425 & 48 & 0.180 \\
4e & 394 & 10,130 & 376 & 429 & 53 & 0.037 \\
\hline
\end{tabular}

Solvent: DMSO; $\mathrm{T}\left({ }^{\circ} \mathrm{C}\right): 25^{\circ} \mathrm{C} ; \lambda$ in $\mathrm{nm} ; \lambda_{\mathrm{exc}}=$ wavelength of excitation; $\lambda_{\mathrm{em}}=$ wavelength of fluorescence emission.

The fluorescence quantum yield $\left(\Phi_{\mathrm{I}}\right)$ is the number of photons being emitted relative to the number of photons being absorbed. It is an essential parameter of fluorophores, allowing to study the fluorescence phenomenon. The $\Phi_{I}$ values of compounds $\mathbf{3 a}, \mathbf{3 c}, \mathbf{3 d}, \mathbf{3 e}, \mathbf{4 d}$ and $\mathbf{4 e}$ are presented in Table 3 . They vary from 0.037 to 0.180 , the highest quantum yields attributed to compounds $3 \mathbf{c}$ and $4 \mathbf{d}$ with nearly equal values of 0.179 and 0.180 , respectively. This indicates that the phenyl group has a positive effect on the fluorescent properties of these compounds.

\subsection{Docking and MD Simulation Studies}

We chose DNA gyrase and topoisomerase IV as putative targets for the docking studies since our compounds resemble somewhat both aminocoumarins and quinolones. Further, the results from the similarity ensemble approach (SEA) server [33] support this selection, since a bacterial topoisomerase (Bacillus subtilis DNA topoisomerase 3) was predicted among the top target candidates based on the 2-oxo-1,2-dihydroquinoline scaffold. GyrB was also found among the predicted targets for the 4 -amide derivative. Thus, we assumed that the modest antimicrobial activity of the compounds could be the result of DNA gyrase/topoisomerase II inhibition.

DNA gyrase and topoisomerase IV are bacterial type II topoisomerases that are responsible for the unwinding of double-stranded DNA during DNA synthesis [67]. While topoisomerase IV can only relax positive helical twists, DNA gyrase can also introduce negative supercoils into the DNA for a smooth replication process by obtaining energy from ATP hydrolysis $[48,68]$. Both enzymes exist as $\mathrm{A}_{2} \mathrm{~B}_{2}$ heterotetramers. DNA gyrase has two 97-kDa gyrase A subunits (GyrA) and two 90-kDA gyrase $B$ subunits (GyrB) (Figure 2). The equivalent subunit pairs in topoisomerase IV are ParC and ParE in Gram-negative bacteria, and GlrA and GlrB in Gram-positive bacteria [10]. 


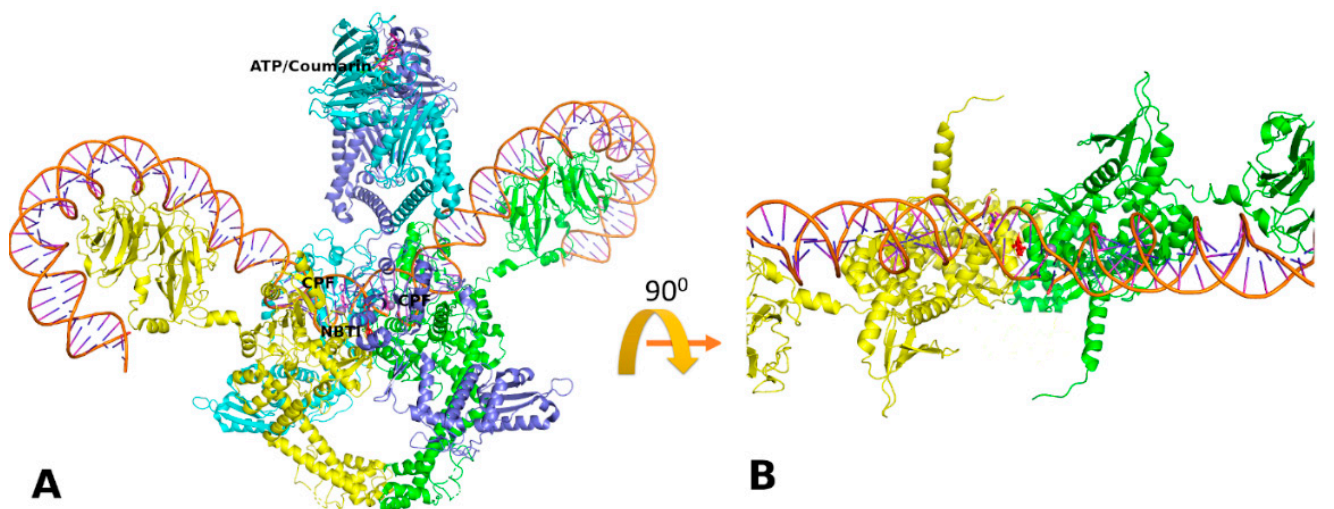

A

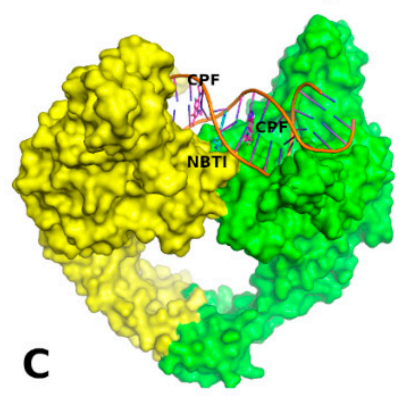

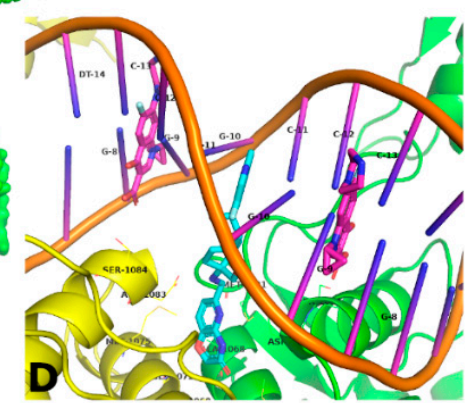

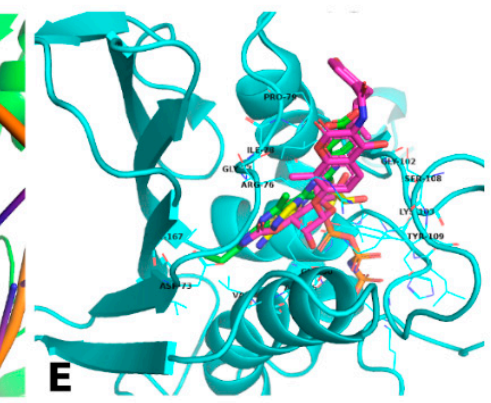

Figure 2. DNA gyrase in complex with DNA and subunit A (GyrA) and subunit B (GyrB) binding ligands. (A) Cartoon representation of the tetrameric enzyme of Escherichia coli in a complex with gepotidacin (red sticks) and ATP analogue ANP (yellow sticks) (Protein Data Bank [PDB] ID: 6RKW). GyrA subunits are in yellow and green, GyrB subunits are in slate blue and in cyan. Different ligand binding sites are labelled (NBTI = novel bacterial topoisomerase inhibitor site; $\mathrm{CPF}=$ ciprofloxacin (fluoroquinolone) binding site; ATP and coumarin bindings sites overlap) and representative ligands from other crystal complexes have been merged in the structure; GyrA: two ciprofloxacin molecules (magenta sticks, from PDB ID: 2XCT); GyrB: novobiocin in magenta sticks from PDB ID: 1S14, "inhibitor $18^{\prime \prime}$, a 4,5'-bithiazole in green sticks from PDB ID: 4 DUH. $\mathrm{Mn}^{2+}$ ions are shown as violet spheres. (B) GyrA subunits are viewed from the top; GyrB subunits have been omitted for clarity. (C) Surface representation of the dimeric GyrA of Staphylococcus aureus in complex with DNA (in cartoon) (PDB ID: 5BS3) and two inhibitors: "compound 7", a tricyclic 1,5-naphthyridinone oxabicyclooctane-linked NBTI (cyan sticks) and ciprofloxacin (from PDB ID: 2 XCT); $\mathrm{Mn}^{2+}$ ions have been omitted. (D) Magnified view of (C) on the GyrA ligand binding sites (protein in cartoon); (E) Magnified view of (A) on the ATP-/coumarin binding site at a GyrB monomer. Interacting residues are shown in lines and labelled along with the interacting DNA bases. Atom colour code for non-carbon atoms: red-oxygen; blue-nitrogen; orange-phosphorus; yellow—sulphur; light blue-fluorine. Hydrogen atoms are omitted for clarity.

Based on the initial analysis of the available DNA gyrase/topoisomerase IV structures of E. coli and S. aureus, we identified putative binding sites for our amino acid based quinolines. The DNA binding site is located in the GyrA and ParC/GrlA subunits while the ATP-binding domain is located in the GyrB and ParE/GlrB subunits [69-71]. The fluoroquinolones (e.g., ciprofloxacin) bind to the GyrA-DNA (ParC/GlrA-DNA) complex (Figure 2D and Supplementary Material Figure S1) whereas coumarins (e.g., novobiocin) block the ATP hydrolysis by binding to the B subunit (Figure 2E and Supplementary Material Figure S2). Since our new quinoline carboxamides resemble both coumarins and fluroquinolones, we investigated their binding at both fluoroquinolone and coumarin binding sites of the bacterial topomerase type II enzymes using molecular docking and MD simulations. Moreover, we also probed the novel bacterial topoisomerase II inhibitor (NBTI) site that is adjacent to the quinolone site (Figure 2A-D) but does not overlap it [72]. NBTIs (e.g., gepotidacin) are a novel 
class of DNA gyrase/topoisomerase IV inhibitors that are being investigated as antibacterials with good potency against fluoroquinolone resistant bacteria [73].

We docked the synthesized compounds to four selected target sites initially occupied by the co-crystallized inhibitors: fluoroquinolone binding site and the NBTI binding site at the GyrA subunit of S. aureus DNA gyrase and coumarin binding site at the GyrB subunit of E. coli DNA gyrase and at the ParE subunit of $E$. coli topoisomerase IV (Table 4). Moreover, binding free energies of both the co-crystallized and docked complexes were also estimated with the molecular mechanics-generalized Born surface area (MM-GBSA) method implemented in the Maestro molecular modeling suite (Schrödinger, LLC, New York, NY, USA). The docking protocol was validated by redocking the co-crystallized inhibitors back to their respective crystal binding sites. Docking scores and MM-GBSA energies of both the co-crystallized compounds and the new amino acid based quinolines are shown in Table 4.

As expected, the co-crystallized inhibitors give relatively low docking scores and/or Prime/MM-GBSA energies at their respective binding sites (the lower the value the better the predicted binding free energy). Although the re-docking scores for novobiocin are relatively poor compared to those of the other co-crystallized compounds (ca. $-4.8 \mathrm{kcal} / \mathrm{mol}$ compared to values between ca. -10 and $-8 \mathrm{kcal} / \mathrm{mol}$ ), the MM-GBSA energy values for novobiocin are comparably low (all crystal compounds show MM-GBSA energy values $\leq-55 \mathrm{kcal} / \mathrm{mol}$, the $4,5^{\prime}$-bithiazole inhibitor at coumarin binding site giving the lowest value of all, $-76.59 \mathrm{kcal} / \mathrm{mol}$ ). MD refinement, however, worsens the MM-GBSA energy value somewhat for all co-crystallized compounds (the change in the energy values ranges between ca. +8 and $+13 \mathrm{kcal} / \mathrm{mol}$ ). The extra precision $(\mathrm{XP})$ mode of docking gives comparable to somewhat lower values than the standard precision (SP) mode.

Docking scores for the amino acid based quinolines are the best at the fluoroquinolone binding site (on average between ca. -11 and $-8 \mathrm{kcal} / \mathrm{mol}$ ) and lowest at the coumarin binding site of $E$. coli ParE of topoisomerase IV (in average between ca. -3.8 and $-6.1 \mathrm{kcal} / \mathrm{mol}$ ) and the NBTI binding site of $S$. aureus DNA gyrase (despite a few exceptions, in average between -4 and $-6.7 \mathrm{kcal} / \mathrm{mol}$ ). The MM-GBSA energy values on the other hand show great variation at the fluoroquinolone binding site (between ca. +2 and $-54 \mathrm{kcal} / \mathrm{mol}$ ). We then performed the short MD refinement for the best-ranked docking poses of all compounds at the fluoroquinolone binding site of $S$. aureus DNA gyrase. This improved the MM-GBSA values significantly (e.g., for compound $4 \mathbf{a}$ from $-14 \mathrm{kcal} / \mathrm{mol}$ to an average of $-43 \mathrm{kcal} / \mathrm{mol}$ ). However, in case of $4 \mathbf{e}$, the MM-GBSA value worsens somewhat, similarly to the co-crystallized ciprofloxacin (from ca. $-54 \mathrm{kcal} / \mathrm{mol}$ to an average of $-41.3 \mathrm{kcal} / \mathrm{mol} \mathrm{vs}$. from $-55 \mathrm{kcal} / \mathrm{mol}$ to an average of $-44.4 \mathrm{kcal} / \mathrm{mol}$, respectively) (Supplementary Figure S19).

The MM-GBSA-energy values are very poor for the compounds at the NBTI site whereas at the coumarin binding site of topoisomerase IV, the values range consistently between ca. $-35 \mathrm{kcal}$ and $-30 \mathrm{kcal} / \mathrm{mol}$. For the coumarin binding site of DNA gyrase, there is more variation and compounds $3 \mathrm{~d}$ and $3 \mathbf{e}$ show values that are even around $-40 \mathrm{kcal} / \mathrm{mol}$. Based on these observations, we selected only the compound with both good XP docking score and MM-GBSA energy value for the MD simulations at the coumarin binding site, compound $3 \mathbf{e}$. At the NBTI binding site we simulated both compounds $3 \mathbf{c}$ and $\mathbf{3 d}$ that showed unusually large negative MM-GBSA energy values, just to observe that the energies were 'normalized' during the refinement of interactions at the site.

In general, the simulated ligand-receptor complexes remained stable during the short MD refinement; see the protein $C \alpha$ atom root mean square deviation (RMSD), root mean square fluctuation (RMSF) and MM-GBSA binding free energy plots in Supplementary Figures S11-S14, S15-S18 and S19-S22, respectively. Interestingly, the complex of E. coli GyrB with the 4,5'-bithiazole ("inhibitor $18^{\prime \prime}$ ) showed some flexibility at the coumarin binding site starting at ca. 3 ns (frame 300) (RMSD and RMSF increased somewhat, Figures S12 and S16, apparently leading to somewhat better interactions, since the MM-GBSA energy decreased somewhat during the second half of the simulation (Supplementary Figure S20). 
Table 4. Glide docking scores and calculated Prime/molecular mechanics-generalized Born surface area (MM-GBSA) binding free energies ( $\left.\Delta \mathrm{G}_{\mathrm{bind}}\right)$ of co-crystallized ligands and the docked amino acid derivatives of quinolines.

\begin{tabular}{|c|c|c|c|c|c|c|c|c|c|c|c|c|}
\hline \multirow[t]{2}{*}{ Ligands } & \multicolumn{3}{|c|}{$\begin{array}{l}\text { Fluoroquinolone Binding site } \\
\text { at GyrA Subunit of S. aureus } \\
\text { DNA Gyrase (PDB ID: 2XCT) }\end{array}$} & \multicolumn{3}{|c|}{$\begin{array}{l}\text { Coumarin Binding } \\
\text { Site at GyrB Subunit of E. coli } \\
\text { DNA Gyrase (PDB ID: 4DUH) }\end{array}$} & \multicolumn{3}{|c|}{$\begin{array}{c}\text { Coumarin Binding } \\
\text { Site at ParE Subunit of E. coli } \\
\text { Topoisomerase IV (PDB ID: 1S14) }\end{array}$} & \multicolumn{3}{|c|}{$\begin{array}{c}\text { NBTI Binding Site } \\
\text { at GyrA Subunit of S. aureus } \\
\text { DNA gyrase (PDB ID: } 5 \mathrm{BS} 3 \text { ) }\end{array}$} \\
\hline & $\begin{array}{l}\text { Glide SP } \\
\text { Docking } \\
\text { Score }\end{array}$ & $\begin{array}{l}\text { Glide XP } \\
\text { Docking } \\
\text { Score }\end{array}$ & $\begin{array}{l}\text { MMGBSA } \\
\Delta \mathrm{G}_{\mathrm{bind}} \\
(\mathrm{kcal} / \mathrm{mol})\end{array}$ & $\begin{array}{l}\text { Glide SP } \\
\text { Docking } \\
\text { Score }\end{array}$ & $\begin{array}{l}\text { Glide XP } \\
\text { Docking } \\
\text { Score }\end{array}$ & $\begin{array}{l}\text { MMGBSA } \\
\Delta \mathrm{G}_{\mathrm{bind}} \\
(\mathrm{kcal} / \mathrm{mol})\end{array}$ & $\begin{array}{l}\text { Glide SP } \\
\text { Docking } \\
\text { Score }\end{array}$ & $\begin{array}{l}\text { Glide XP } \\
\text { Docking } \\
\text { Score }\end{array}$ & $\begin{array}{l}\text { MMGBSA } \\
\Delta \mathrm{G}_{\text {bind }} \\
(\mathrm{kcal} / \mathrm{mol})\end{array}$ & $\begin{array}{l}\text { Glide SP } \\
\text { Docking } \\
\text { Score }\end{array}$ & $\begin{array}{l}\text { Glide XP } \\
\text { Docking } \\
\text { Score }\end{array}$ & $\begin{array}{l}\text { MMGBSA } \\
\Delta \mathrm{G}_{\text {bind }} \\
\text { (kcal/mol) }\end{array}$ \\
\hline Ciprofloxacin & $-8.257^{a}$ & $-8.096^{a}$ & $\begin{array}{c}-54.99 / \\
-44.29^{b} \\
\end{array}$ & - & & - & - & & - & - & & - \\
\hline Inhibitor $18\left(4,5^{\prime}\right.$-bithiazole & - & & - & $-10.075^{a}$ & $-8.834^{a}$ & $\begin{array}{l}-76.59 / \\
-68.27^{b}\end{array}$ & - & & - & - & & - \\
\hline Novobiocin & - & & - & - & & - & $-4.801^{a}$ & $-4.857^{a}$ & $\begin{array}{l}-67.07 / \\
-55.58^{b}\end{array}$ & - & & - \\
\hline Compound 7 (NBTI) & - & & - & - & & - & - & & - & $-8.974^{a}$ & $-7.902^{a}$ & $\begin{array}{l}-71.40 / \\
-58.00^{b}\end{array}$ \\
\hline $3 \mathbf{a}$ & -8.743 & -7.209 & $\begin{array}{l}-18.53 / \\
-19.36^{b}\end{array}$ & -7.728 & -6.521 & -25.70 & -6.111 & -3.806 & -33.35 & -5.046 & -4.710 & -12.30 \\
\hline $3 b$ & -9.781 & -9.969 & $\begin{array}{r}3.86 / \\
-22.56^{b} \\
\end{array}$ & -8.111 & -6.771 & -17.81 & -5.529 & -4.587 & -35.53 & -5.494 & -6.636 & -15.69 \\
\hline $3 c$ & -9.802 & -8.117 & $\begin{array}{r}2.10 / \\
-24.63^{b} \\
\end{array}$ & -7.375 & -6.847 & -38.99 & -6.122 & -4.748 & -34.59 & -4.262 & -6.291 & $\begin{array}{c}-1131.43^{c} / \\
-18.55^{b}\end{array}$ \\
\hline $3 d$ & -8.631 & -9.060 & $\begin{array}{l}-21.00 / \\
-24.91^{b} \\
\end{array}$ & -7.440 & -7.368 & -40.05 & -6.028 & -4.394 & -34.63 & -5.011 & -5.986 & $\begin{array}{c}-1384.35^{c} / \\
-24.25^{b}\end{array}$ \\
\hline $3 e$ & -10.203 & -10.826 & $\begin{array}{l}-18.99 / \\
-27.88^{b} \\
\end{array}$ & -7.116 & -7.669 & $\begin{array}{l}-38.03 / \\
-48.84^{b} \\
\end{array}$ & -6.481 & -6.765 & $\begin{array}{l}-34.60 / \\
-33.52^{b} \\
\end{array}$ & -6.592 & -8.059 & -3.46 \\
\hline $4 a$ & -8.494 & -8.824 & $\begin{array}{l}-14.34 / \\
-43.03^{b} \\
\end{array}$ & -7.464 & -7.125 & -24.59 & -5.026 & -3.806 & -30.38 & -5.595 & -5.645 & -11.44 \\
\hline $4 b$ & -8.915 & -9.346 & $\begin{array}{c}-4.66 / \\
-20.28^{b}\end{array}$ & -7.439 & -7.279 & -18.40 & -5.472 & -4.360 & -32.37 & -6.54 & -7.085 & -15.27 \\
\hline $4 c$ & -8.812 & -8.718 & $\begin{array}{r}-2.69 / \\
-20.97^{b} \\
\end{array}$ & -3.053 & -6.364 & -32.44 & -6.015 & -3.743 & -33.53 & -5.823 & -6.663 & -12.12 \\
\hline $4 \mathrm{~d}$ & -7.311 & -9.068 & $\begin{array}{l}-20.88 / \\
-35.56^{b}\end{array}$ & -2.552 & -6.415 & -21.79 & -5.228 & -3.733 & -31.26 & -5.114 & -5.672 & -12.26 \\
\hline $4 e$ & -9.109 & -11.419 & $\begin{array}{r}-53.79 / \\
-41.26^{b} \\
\end{array}$ & -4.405 & -7.064 & -37.62 & -5.688 & -4.487 & -30.26 & -6.684 & -8.479 & -18.14 \\
\hline
\end{tabular}

${ }^{a}$ Re-docking score; ${ }^{b}$ Binding free energy values before/after molecular dynamics (MD); the latter value is an average value over the 10-ns MD simulation trajectory; ${ }^{c}$ Large non-realistic values before MD are likely due to the fact that these compounds initially interacted only with DNA; after MD the compounds had interactions also with the protein, whereby the values were reduced to a realistic level. Color code: Strong interaction is indicated by dark green (low binding free energy or docking score) and weak interaction as yellow (high binding free energy or docking score). PDB ID - Protein Data Bank entry code. 


\subsubsection{Fluroquinolone Binding Site at GyrA}

The fluoroquinolone class of gyrase inhibitors binds to DNA-bound GyrA (and the corresponding topoisomerase IV ParC) subunits. The two equal fluoroquinolone binding sites in the GyrA monomers flank the NBTI binding site on both sides (Figure 2B-D). In the crystal structure of S. aureus DNA gyrase, ciprofloxacin coordinates to the $\mathrm{Mn} 2+$ ion with its carboxylic acid-keto acid moiety. It also hydrogen bonds to Ser84 (Ser1084 in PDB ID: 2XCT) with its carboxylic group and it forms aromatic pi-pi stacking interactions with the proximal DNA bases (Figure 2D and Supplementary Material Figure S3). In addition to various hydrophobic contacts with the surrounding residues, the protonated piperazine nitrogen may form a salt bridge with Glu477 and the carboxylic group with Arg122 (Arg1122 in PDB ID: 2XCT) from the other GyrA chain.

The interactions of compounds $3 \mathbf{e}$ and $4 \mathbf{e}$ that had the best docking scores are shown in Figure 3. In general, they both show similar interactions, apart from the additional possibility of halogen bonds between the bromine and e.g., Asp437 for 4e. The carboxylic group forms hydrogen bonds with Ser84, the amide carbonyl with Arg122 and the quinoline ring engages in pi-cation interactions with Arg122. The carboxylic group also coordinates with the $\mathrm{Mn}^{2+}$ ion and the indole ring forms pi-pi stacking interactions with the guanine base 9. During the MD refinement, many direct interactions turn to (or swap between direct and) water-mediated interactions (see Supplementary Material, Figures S3 and S7). For example, the water-mediated hydrogen bonding interactions of 4e with Asp83 (Asp1083 in PDB ID: 2XCT), Ser84 and Arg122 are persistent during the simulation. Ciprofloxacin on the other hand shows only occasionally water-mediated interactions with Arg122, Ser84 and Ser85 (Ser1085 in PDB ID: 2XCT). Direct hydrogen bond interactions with Ser84 and Arg122 are present most of the time, as well as either ionic or hydrogen bond interaction with Glu477. Ion coordination with $\mathrm{Mn} 2+$ and stacking with especially guanine base 9 are also prevalent throughout the simulation. Despite the increase in solvent-mediated interactions, compound 4e shows comparable MM-GBSA energies with ciprofloxacin during the 10-ns simulation (Table 4, Supplementary Figure S19) at the S. aureus GyrA fluoroquinolone binding site.

\subsubsection{Coumarin Binding Site at GyrB and ParE}

Since DNA gyrase and topoisomerase IV share conserved active sites, small-molecular inhibitors targeted at these sites can inhibit both enzymes simultaneously. For example, both aminocoumarin and 4,5'-bithiazole classes of gyrase inhibitors bind to the coumarin site of GyrB and ParE, and therefore we did a comparative docking of our compounds to both enzyme subunits.

The active DNA Gyrase B subunit is a dimer where Tyr-5' from the other monomer interacts with the guanidinium group of Arg136. Novobiocin prevents this dimerization when its coumarin ring replaces the absent Tyr-5' [44]. For an effective interaction, the coumarin carbonyl oxygen is located at

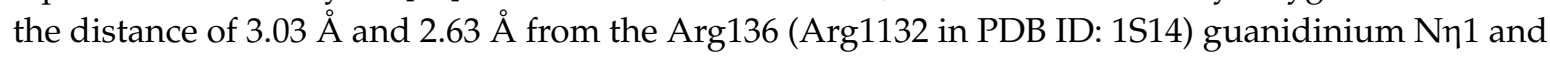
$\mathrm{N} \eta 2$ atoms, respectively. Another arginine, Arg76 (Arg1072), forms cation-pi interactions with the coumarin ring. On the other hand, the E. coli GyrB structure with a 4,5'-bithiazole ('inhibitor 18') (PDB ID: 4DUH) reveals additional ligand interactions with Gly101 and Lys103 that are present in a flexible loop. Gly101 backbone carbonyl forms a hydrogen bond with the $\mathrm{NH}$ of the amino benzoic acid moiety and Lys103 forms cation-pi interactions with the thiazole rings, thus stabilising the flexible loop region. The docked compounds 3a and 3e show different orientations in the binding pocket, most likely due to the presence/absence of the indole moiety (Figure 4). Both form pi-cation interactions with Lys103 and a hydrogen bond with Gly101. However, $3 \mathbf{e}$ has also a salt bridge/hydrogen bonds with Arg76.

While both novobiocin and the 4,5'-bithiazole inhibitor maintain multiple strong interactions during the MD simulations, compound 3e maintains only the interactions with Arg76 and Lys103 at GyrB (see Supplementary Material, Figures S4, S5, S8 and S9). Water-mediated interactions with Arg136 are also persistent and a hydrogen bond is formed with Gly101. In ParE, water-mediated interactions with Asp81 (Asp1077) and Arg76 (Arg1072) are maintained and a water-mediated or a direct hydrogen bond from the indole nitrogen is formed at times with Gly77 (Gly1073). 


\subsubsection{NBTI Binding Site at GyrA Dimer Interface}

The tricyclic-1,5-naphthyridinone compound 7 (NBTI) binds tightly at the dimer interface of GyrA subunits and interacts with the same residues from both monomers: for example, with Asp83 (Asp1083 in PDB ID: 5BS3) via hydrogen bonds, with Met121 (Met1121) through van der Waals interactions and with cytosine base 11 via aromatic stacking. These interactions are maintained during the MD refinement (Supplementary Material, Figures S6 and S10). The quinoline ring of the docked compounds 3c and 3d inserts between the DNA bases to form pi-pi stacking interactions and the amide moiety may also engage in hydrogen bonding with the bases. The other part of the compounds is solvent exposed and during the MD simulations forms mainly water-mediated interactions with the surrounding residues (such as Asp83 and Arg122 (Arg1122) in case of compound 3c; see Supplementary Material, Figures S6B and S10B).
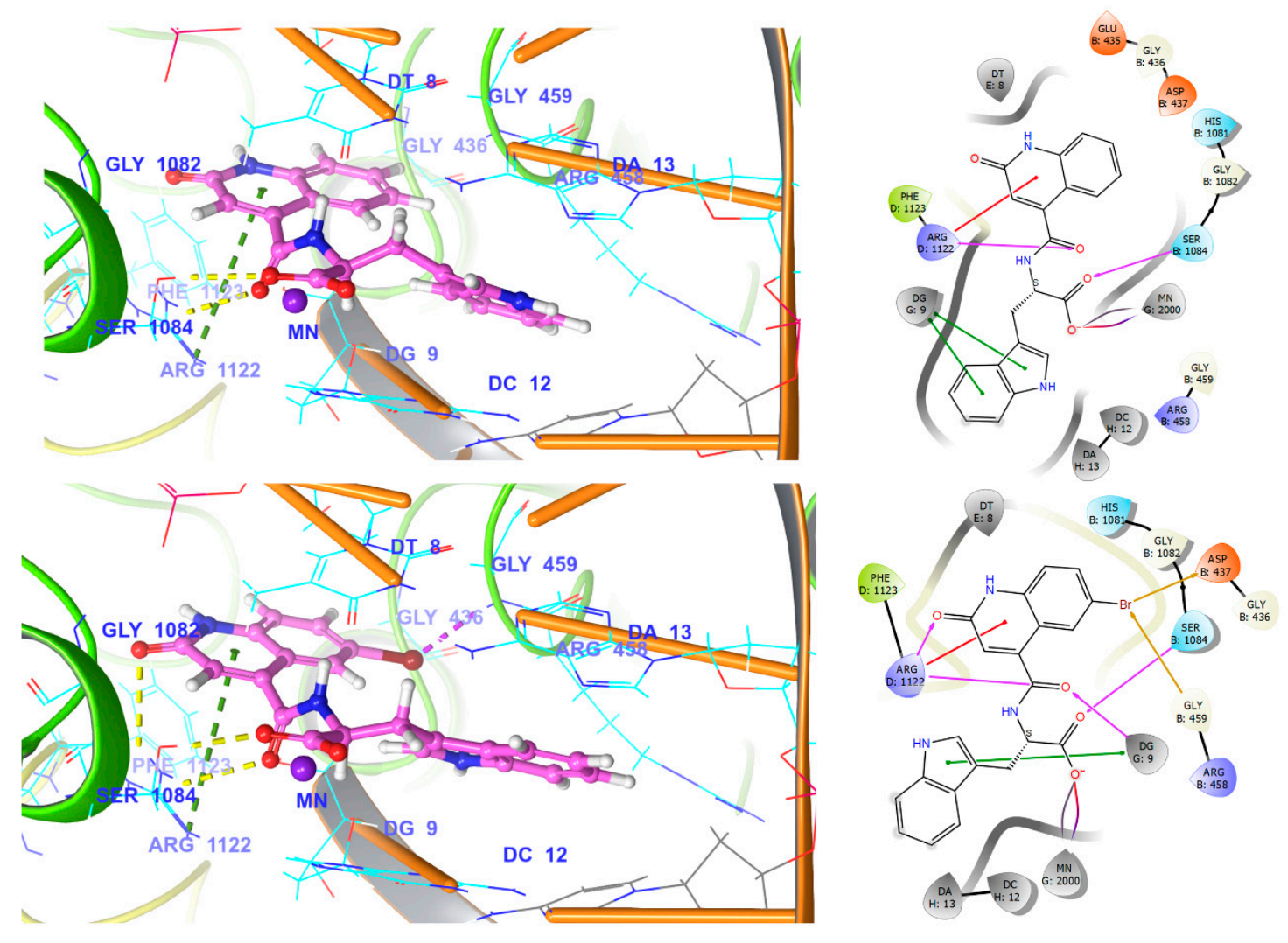

Figure 3. Interactions of quinoline amino acids at the fluoroquinolone binding site (magenta ball and sticks) of S. aureus DNA-gyrase subunit A (PDB ID: 2XCT) in 3D (left panel; protein chains in yellow/green cartoon; DNA in orange; key interacting residues in cyan sticks; Mn2+ ion shown as a violet sphere; interactions as dashed lines; color of interaction type: yellow-hydrogen bonds; green.-pi-cation interaction; cyan-pi-pi stacking; dark pink—salt bridge; magenta-halogen bond) and in 2D (right panel). Top: compound 3e. Bottom: compound 4e.

\subsubsection{Comparison of Key Interactions of Ligands at the Fluoroquinolone Binding Site}

Based on the docking and simulation studies, the fluoroquinolone site could be one possible binding site for our compounds at DNA gyrase. Positions 3 and 4 in the quinolone structure are crucial for the interaction with the $\mathrm{Mg}^{2+}$ ion and Ser84 at the enzyme active site (Figure 5). Modification of the basic quinolone scaffold to a quinazolidinedione shows, instead of these key interactions, an additional H-bond interaction with Arg112 and the carbonyl oxygen at position 2 [10]. At the fluoroquinolone site, our compounds show a similar interaction with Arg112 as observed for quinazolidinediones (Figure 5). However, they may also interact with the cation and Ser84 through the carboxylic acid moiety. Of note 
is that the R7 substituent of quinolones and quinazolidinediones interacts strongly with topoisomerase IV but it also leads to increased susceptibility towards binding to human topoisomerase II $\alpha$ [10].
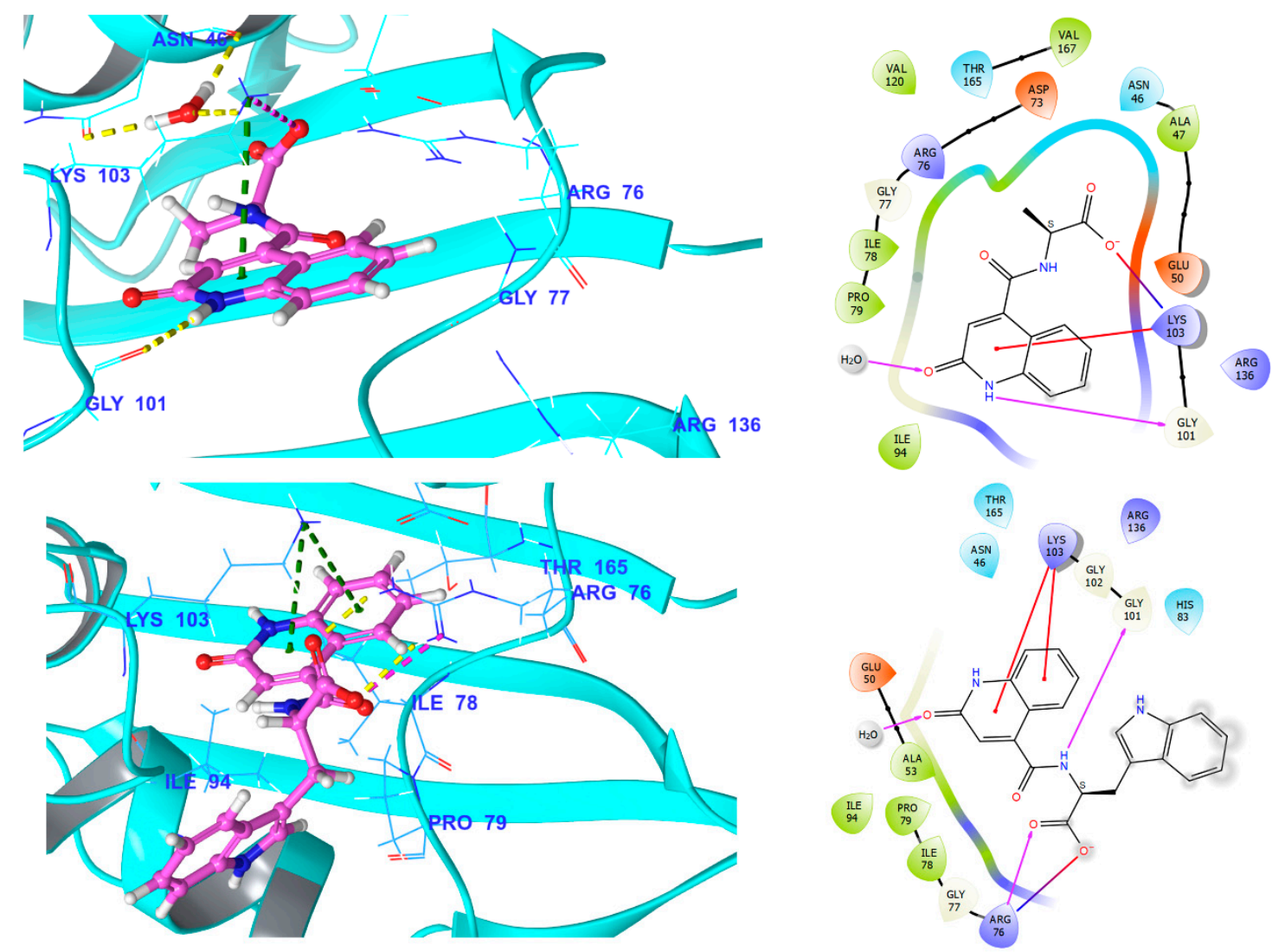

Figure 4. Interactions of docked quinoline amino acids at the coumarin binding site (magenta ball and sticks) of E. coli DNA gyrase subunit B (PDB ID: 4DUH) in 3D (left panel; protein in cyan cartoon; key interacting residues in blue sticks; interactions as dashed lines; color of interaction type: yellow—hydrogen bonds; green—pi-cation interaction; cyan—pi-pi stacking; dark pink—salt bridge) and in 2D (right panel). Top: compound 3a. Bottom: compound 3e.

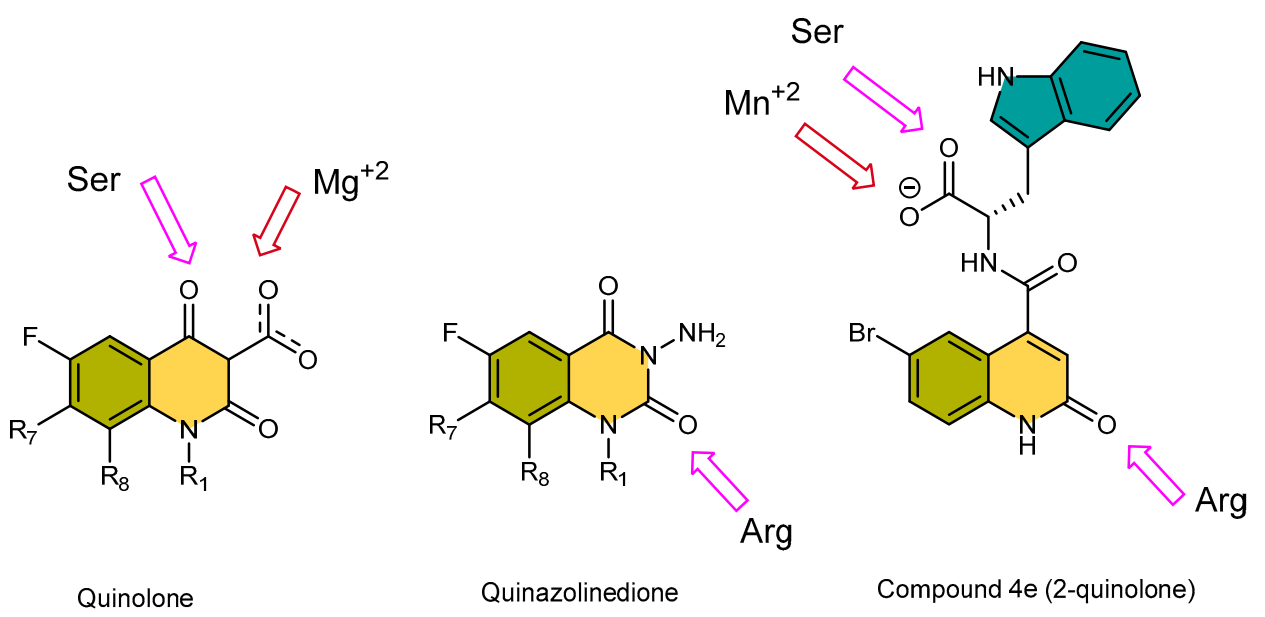

Figure 5. Key interacting structural moieties of quinolones and quinazolinediones in the fluoroquinolone binding site compared to the predicted interactions of compound 4e (color scheme: red arrow-metal ion interaction; pink arrow-H-bond interaction). 


\section{Conclusions}

In this work, a series of new amino acid derivatives of 2-oxoquinolines (3a-e and $4 \mathbf{a}-\mathbf{e}$ ) was synthesized through a practical and efficient approach. The reported synthesis protocol offers several advantages, such as simplicity of operation, high product yield and safe reaction conditions. The synthesized compounds were characterized by different spectroscopic techniques such as ${ }^{1} \mathrm{H}$ and ${ }^{13} \mathrm{C}$ NMR spectroscopy and ESI-TOF mass spectrometry. The antibacterial activity of these compounds was evaluated against E. coli ATCC 25922, S. aureus ATCC 29213, P. aeruginosa ATCC 27853 and B. subtilis ATCC 3366 bacterial strains. All newly synthesized amino acid-based quinolones showed better antimicrobial activities than their corresponding amino acid esters. Compound 3a appeared as the most potent antimicrobial agent with a moderate MIC of $0.62 \mathrm{mg} / \mathrm{mL}$ against all the bacterial strains tested. Compound 3e showed the lowest MIC (0.31 mg/mL) against S. aureus ATCC 29213. Moreover, the fluorescent properties of compounds $4 \mathbf{e}$ and $4 \mathbf{d}$ make them potentially interesting as novel fluorophores.

The molecular docking and MD simulation studies of these new compounds at the putative bacterial targets, DNA gyrase and topoisomerase-IV, suggest favourable interactions with the catalytic Ser-84 at the fluoroquinolone binding site. Other persistent interactions at this site were observed with Arg122 and Asp83. Based on the analysis of the molecular interactions at other possible ligand-binding sites in DNA gyrase and topoisomerase-IV, the compounds are not predicted to have as much affinity to these sites as to the fluoroquinolone binding site, which was somewhat expected due to their quinoline scaffold. The different binding mode and additional key interactions of the amino acid based quinolines at the fluoroquinolone site may prove beneficial for circumventing the development of antibacterial resistance as observed for fluoroquinolones (arising often from a mutation at Ser84). Naturally, a rigorous optimization process for this series of compounds is required to obtain potent candidate compounds with high antibacterial activity and ability to treat quinolone-resistant bacterial strains in the clinic. Enzyme assays, biophysical experiments and structural biology studies are also required to verify the binding of these compounds at the studied target sites. Overall, the results from this study provide useful insights into the characteristics of amino acid based quinolines as potential leads for novel antimicrobials.

Supplementary Materials: The following are available online at http://www.mdpi.com/2218-0532/88/4/57/s1. Supplementary Figures, Equilibration protocol for MD and the NMR spectra for the synthesized compounds.

Author Contributions: Conceptualization: O.M. and R.S.; methodology, O.M. and S.E.A.; computational analysis, R.B., S.C., Y.K.R. and O.M.H.S.-A.; structural analysis, O.M. and R.S.; antibacterial activity, E.M.E.H.; resources, O.M.H.S.-A., A.B.T. and E.M.E.H.; writing—original draft preparation, O.M., S.C., R.B. and O.M.H.S.-A.; writing-review and editing, O.M.H.S.-A., R.B. and A.B.T.; visualization, E.M.E.H.; supervision, O.M.H.S.-A., S.C. and E.M.E.H.; supervision of computational modeling, O.M.H.S.-A. All authors have read and agreed to the published version of the manuscript.

Funding: R.B. gratefully acknowledges the financial support of the Academy of Finland (mobility grant).

Acknowledgments: The Sigrid Jusélius Foundation, Biocenter Finland Bioinformatics and Drug Discovery and Chemical Biology networks, CSC IT Center for Science, Joe, Pentti and Tor Borg Memorial Fund and Mark Johnson and Jukka Lehtonen are gratefully acknowledged for the excellent computational infrastructure at the Åbo Akademi University.

Conflicts of Interest: The authors declare no conflict of interest.

\section{References}

1. Theuretzbacher, U.; Gottwalt, S.; Beyer, P.; Butler, M.; Czaplewski, L.; Lienhardt, C.; Moja, L.; Paul, M.; Paulin, S.; Rex, J.H.; et al. Analysis of the clinical antibacterial and antituberculosis pipeline. Lancet Infect. Dis. 2019, 19, 40-50. [CrossRef]

2. Lesher, G.Y.; Froelich, E.J.; Gruett, M.D.; Bailey, J.H.; Brundage, R.P. 1,8-Naphthyridine Derivatives. A New Class of Chemotherapeutic Agents. J. Med. Chem. 1962, 5, 1063-1065. [CrossRef] [PubMed] 
3. Aldred, K.J.; Kerns, R.J.; Osheroff, N. Mechanism of quinolone action and resistance. Biochemistry 2014, 53, 1565-1574. [CrossRef] [PubMed]

4. Hernandez, A.; Sanchez, M.B.; Martínez, J.L. Quinolone resistance: Much more than predicted. Front. Microbiol. 2011, 2, 22. [CrossRef] [PubMed]

5. Andersson, M.I. Development of the quinolones. J. Antimicrob. Chemother. 2003, 51, 1-11. [CrossRef]

6. Emmerson, A.M. The quinolones: Decades of development and use. J. Antimicrob. Chemother. 2003, 51, 13-20. [CrossRef] [PubMed]

7. Hooper, D.C. Mode of action of fluoroquinolones. Drugs 1999, 58, 6-10. [CrossRef]

8. Davis, R.L.; Kelly, H.W.; Quenzer, R.W.; Standefer, J.; Steinberg, B.; Gallegos, J. Effect of norfloxacin on theophylline metabolism. Antimicrob. Agents Chemother. 1989, 33, 212-214. [CrossRef]

9. Lange, R.P.; Locher, H.H.; Wyss, P.C.; Then, R.L. The targets of currently used antibacterial agents: Lessons for drug discovery. Curr. Pharm. Des. 2007, 13, 3140-3154. [CrossRef]

10. Pham, T.D.; Ziora, Z.M.; Blaskovich, M.A. Quinolone antibiotics. Medchemcomm 2019, 10, $1719-1739$. [CrossRef]

11. Silver, L.L. Appropriate Targets for Antibacterial Drugs. Cold Spring Harb. Perspect. Med. 2016, 6, a030239. [CrossRef] [PubMed]

12. Neuhauser, M.M.; Weinstein, R.A.; Rydman, R.; Danziger, L.H.; Karam, G.; Quinn, J.P. Antibiotic resistance among gram-negative bacilli in US intensive care units: Implications for fluoroquinolone use. JAMA 2003, 289, 885-888. [CrossRef] [PubMed]

13. Hyatt, J.M.; McKinnon, P.S.; Zimmer, G.S.; Schentag, J.J. The importance of pharmacokinetic/ pharmacodynamic surrogate markers to outcome. Focus on antibacterial agents. Clin. Pharmacokinet. 1995, 28, 143-160. [CrossRef] [PubMed]

14. Hooper, D.C.; Jacoby, G.A. Mechanisms of drug resistance: Quinolone resistance. Ann. N. Y. Acad. Sci. 2015, 1354, 12-31. [CrossRef]

15. Correia, S.; Poeta, P.; Hébraud, M.; Capelo, J.L.; Igrejas, G. Mechanisms of quinolone action and resistance: Where do we stand? J. Med. Microbiol. 2017, 66, 551-559. [CrossRef]

16. Katagi, M.; Bolakatti, G.; Badiger, A.; Satyanarayana, D.; Mamledesai, S.; Sujatha, M. Synthesis, Spectral Characterization and Antimicrobial Activity of Substituted Thiazolyl Derivatives of 2-Quinolones. Drug Res. 2013, 63, 53-59. [CrossRef]

17. Khamkhenshorngphanuch, T.; Kulkraisri, K.; Janjamratsaeng, A.; Plabutong, N.; Thammahong, A.; Manadee, K.; Na Pombejra, S.; Khotavivattana, T. Synthesis and Antimicrobial Activity of Novel 4-Hydroxy-2-quinolone Analogs. Molecules 2020, 25, 3059. [CrossRef]

18. Jayashree, B.S.; Thomas, S.; Nayak, Y. Design and synthesis of 2-quinolones as antioxidants and antimicrobials: A rational approach. Med. Chem. Res. 2010, 19, 193-209. [CrossRef]

19. Dhiman, P.; Arora, N.; Thanikachalam, P.V.; Monga, V. Recent advances in the synthetic and medicinal perspective of quinolones: A review. Bioorg. Chem. 2019, 92, 103291. [CrossRef]

20. Arya, K.; Agarwal, M. Microwave prompted multigram synthesis, structural determination, and photo-antiproliferative activity of fluorinated 4-hydroxyquinolinones. Bioorg. Med. Chem. Lett. 2007, 17, 86-93. [CrossRef]

21. Valadbeigi, E.; Ghodsi, S. Synthesis and Study of Some New Quinolone Derivatives Containing a 3-acetyl Coumarin for Their Antibacterial and Antifungal Activities. IJPR 2017, 16, 554-564. [PubMed]

22. Wenjie, X.; Xueyao, L.; Guixing, M.; Hongmin, Z.; Ya, C.; Johannes, K.; Jie, X.; Song, W. $\mathrm{N}$-thiadiazole-4-hydroxy-2-quinolone-3-carboxamides bearing heteroaromatic rings as novel antibacterial agents: Design, synthesis, biological evaluation and target identification. Eur. J. Med. Chem. 2020, 188, 112022.

23. Townsend, C.A.; Brown, A.M. Nocardicin A: Biosynthetic experiments with amino acid precursors. J. Am. Chem. Soc. 1983, 105, 913-918. [CrossRef]

24. Moloney, M.G. Excitatory amino acids. Nat. Prod. Rep. 1999, 16, 485-498. [CrossRef] [PubMed]

25. Hughes, A.B. Amino Acids, Peptides and Proteins in Organic Chemistry: Building Blocks, Catalysis and Coupling Chemistry; Wiley-VCH: Weinheim, Germany, 2011; pp. 83-114.

26. Ohashi, Y.; Onuma, R.; Nagakuma, T.; Ogawa, T.; Naude, R.; Nokihara, K.; Muramoto, K. Antioxidant properties tripeptides revealed by a comparison of six different assays. Food Sci. Technol. Res. 2016, 21, 695-704. [CrossRef] 
27. Wei, Q.Y.; Jiang, H.; Zhang, J.X.; Zhang, C.; Guo, P.F. Antimicrobial activities of the cinnamoyl amide of amino acid derivatives. Asian J. Chem. 2012, 24, 2383-2388.

28. Ghalehshahi, H.G.; Balalaie, S.; Aliahmadi, A.; Moghimi, R. Synthesis of 4-N- $\alpha$-coumaryl amino acids and investigation of their antioxidant, antimicrobial activities and fluorescence spectra. Amino Acids 2018, 50, 1461-1470. [CrossRef]

29. Shivaraj, Y.; Naveen, H.M.; Vijayakumar, R.G.; Kumar, D.B. Design, Synthesis and Antibacterial Activity Studies of Novel Quinoline Carboxamide Derivatives. J. Korean Chem. Soc. 2013, 57, 241-324. [CrossRef]

30. Khalid, M.; Ali, A.; Jawaria, R.; Asghar, M.A.; Asim, S.; Khan, M.U.; Hussain, R.; ur Rehman, M.F.; Ennise, C.J.; Akram, M.S. First Principles Study of Electronic and Nonlinear Optical Properties of A-D- $\pi-A$ and D-A-D- $\pi-\mathrm{A}$ Configured Compounds Containing Novel Quinoline-Carbazole Derivatives. RSC Adv. 2020, 10, 22273-22283. [CrossRef]

31. Basri, D.F.; Luoi, C.K.; Azmi, A.M.; Latip, J. Evaluation of the Combined Effects of Stilbenoid from Shorea gibbosa and Vancomycin against Methicillin-Resistant Staphylococcus aureus (MRSA). Pharmaceuticals 2012, 5, 1032-1043. [CrossRef]

32. Ouedrhiri, W.; Bouhdid, S.; Balouiri, M.; Lalami, A.E.O.; Moja, S.; Chahdi, F.O.; Greche, H. Chemical composition of Citrus aurantium L. leaves and zest essential oils, their antioxidant, antibacterial single and combined effects. J. Chem. Pharm. 2015, 7, 78-84.

33. Keiser, M.J.; Roth, B.L.; Armbruster, B.N.; Ernsberger, P.; Irwin, J.J.; Shoichet, B.K. Relating protein pharmacology by ligand chemistry. Nat. Biotech. 2007, 25, 197-206. [CrossRef] [PubMed]

34. The UniProt Consortium. UniProt: A worldwide hub of protein knowledge. Nucleic Acids Research 2019, 47, 506-515. [CrossRef]

35. Madeira, F.; Park, Y.M.; Lee, J.; Buso, N.; Gur, T.; Madhusoodanan, N.; Basutkar, P.; Tivey, A.R.N.; Potter, S.C.; Finn, R.D.; et al. The EMBL-EBI search and sequence analysis tools APIs in 2019. Nucleic Acids Res. 2019, 47, 636-641. [CrossRef] [PubMed]

36. Berman, H.M.; Westbrook, J.; Feng, Z.; Gilliland, G.; Bhat, T.N.; Weissig, H.; Shindyalov, I.N.; Bourne, P.E. The Protein Data Bank. Nucleic Acids Res. 2000, 28, 235-242. [CrossRef]

37. Hu, Y.; Shi, H.; Zhou, M.; Ren, Q.; Zhu, W.; Zhang, W.; Zhang, Z.; Zhou, C.; Liu, Y.; Ding, X.; et al. Discovery of Pyrido[2,3-b]indole Derivatives with Gram-Negative Activity Targeting Both DNA Gyrase and Topoisomerase IV. J. Med. Chem. 2020, 17, 9623-9649. [CrossRef]

38. Edwards, M.J.; Flatman, R.H.; Mitchenall, L.A.; Stevenson, C.E.; Le, T.B.; Clarke, T.A.; McKay, A.R.; Fiedler, H.P.; Buttner, M.J.; Lawson, D.M.; et al. A Crystal Structure of the Bifunctional Antibiotic Simocyclinone D8, Bound to DNA Gyrase. Science 2009, 5958, 1415-1418. [CrossRef]

39. Singh, S.B.; Kaelin, D.E.; Wu, J.; Miesel, L.; Tan, C.M.; Black, T.; Nargund, R.; Meinke, P.T.; Olsen, D.B.; Lagrutta, A.; et al. Tricyclic 1,5-Naphthyridinone Oxabicyclooctane-Linked Novel Bacterial Topoisomerase Inhibitors as Broad-Spectrum Antibacterial Agents-SAR of Left-Hand-Side Moiety (Part-2). Bioorg. Med. Chem. Lett. 2015, 25, 1831-1835. [CrossRef]

40. Singh, S.B.; Kaelin, D.E.; Wu, J.; Miesel, L.; Tan, C.M.; Meinke, P.T.; Olsen, D.; Lagrutta, D.; Bradley, P.; Lu, J.; et al. Oxabicyclooctane-Linked Novel Bacterial Topoisomerase Inhibitors as Broad Spectrum Antibacterial Agents. ACS Med. Chem. Lett. 2014, 5, 609-614. [CrossRef]

41. Gibson, G.; Bax, B.; Chan, P.F.; Osheroff, N. Mechanistic and Structural Basis for the Actions of the Antibacterial Gepotidacin against Staphylococcus aureus Gyrase Elizabeth. ACS Infect. Dis. 2019, 4, 570-581. [CrossRef]

42. Vanden Broeck, A.; Lotz, C.; Ortiz, J.; Lamour, V. Cryo-EM structure of the complete E. coli DNA gyrase nucleoprotein complex. Nat. Commun. 2019, 10, 4935. [CrossRef] [PubMed]

43. Stanger, F.V.; Dehio, C.; Schirmer, T. Structure of the N-Terminal Gyrase B Fragment in Complex with ADP Pi Reveals Rigid-Body Motion Induced by ATP Hydrolysis. PLoS ONE 2014, 9, e107289. [CrossRef] [PubMed]

44. Holdgate, G.A.; Tunnicliffe, A.; Ward, W.H.; Weston, S.A.; Rosenbrock, G.; Barth, P.T.; Taylor, I.W.; Pauptit, R.A.; Timms, D. The Entropic Penalty of Ordered Water Accounts for Weaker Binding of the Antibiotic Novobiocin to a Resistant Mutant of DNA Gyrase: A Thermodynamic and Crystallographic Study Geoffrey. Biochemistry 1997, 32, 9663-9673. [CrossRef] [PubMed]

45. Vanden Broeck, A.; McEwen, A.G.; Chebaro, Y.; Potier, N.; Lamour, V. Structural Basis for DNA Gyrase Interaction with Coumermycin A1. J. Med. Chem. 2019, 62, 4225-4231. [CrossRef] [PubMed] 
46. Mesleh, M.F.; Cross, J.B.; Zhang, J.; Kahmann, J.; Andersen, O.A.; Barker, J.; Cheng, R.K.; Felicetti, B.; Wood, M.; Hadfield, A.T.; et al. Fragment-based discovery of DNA gyrase inhibitors targeting the ATPase subunit of GyrB. Bioorg. Med. Chem. Lett. 2016, 26, 1314-1318. [CrossRef] [PubMed]

47. Sherer, B.A.; Hull, K.; Green, O.; Basarab, G.; Hauck, S.; Hill, P.; Loch, J.T.; Mullen, G.; Bist, S.; Bryant, J.; et al. Pyrrolamide DNA gyrase inhibitors: Optimization of antibacterial activity and efficacy. Bioorg. Med. Chem. Lett. 2011, 21, 7416-7420. [CrossRef]

48. Brvar, M.; Perdih, A.; Renko, M.; Anderluh, G.; Turk, D.; Solmajer, T. Structure-Based Discovery of Substituted 4,5'-Bithiazoles as Novel DNA Gyrase Inhibitors. J. Med. Chem. 2012, 55, 6413-6426. [CrossRef]

49. Bellon, S.; Parsons, J.D.; Wei, Y.; Hayakawa, K.; Swenson, L.L.; Charifson, P.S.; Lippke, J.A.; Aldape, R.; Gross, C.H. Crystal Structures of Escherichia Coli Topoisomerase IV ParE Subunit (24 and 43 Kilodaltons): A Single Residue Dictates Differences in Novobiocin Potency against Topoisomerase IV and DNA Gyrase. Antimicrob. Agents Chemother. 2004, 5, 1856-1864. [CrossRef]

50. Roos, K.; Wu, C.; Damm, W.; Reboul, M.; Stevenson, J.M.; Lu, C.; Dahlgren, M.K.; Mondal, S.; Chen, W.; Wang, L.; et al. OPLS3e: Extending Force Field Coverage for Drug-Like Small Molecules. J. Chem. Theory Comput. 2019, 3, 1863-1874. [CrossRef]

51. Greenwood, J.R.; Calkins, D.; Sullivan, A.P.; Shelley, J.C. Towards the comprehensive, rapid, and accurate prediction of the favorable tautomeric states of drug-like molecules in aqueous solution. J. Comput. Aided Mol. Des. 2010, 24, 591-604. [CrossRef]

52. Shelley, J.C.; Cholleti, A.; Frye, L.; Greenwood, J.R.; Timlin, M.R.; Uchimaya, M. Epik: A software program for pKa prediction and protonation state generation for drug-like molecules. J. Comput. Aided Mol. Des. 2007, 21, 681-691. [CrossRef] [PubMed]

53. Sastry, G.M.; Adzhigirey, M.; Day, T.; Annabhimoju, R.; Sherman, W. Protein and ligand preparation: Parameters, protocols, and influence on virtual screening enrichments. J. Comput. Aided Mol. Des. 2013, 3, 221-234. [CrossRef] [PubMed]

54. Friesner, R.A.; Murphy, R.B.; Repasky, M.P.; Frye, L.L.; Greenwood, J.R.; Halgren, T.A.; Sanschagrin, P.C.; Mainz, D.T. Extra Precision Glide: Docking and Scoring Incorporating a Model of Hydrophobic Enclosure for Protein-Ligand Complexes. J. Med. Chem. 2006, 49, 6177-6196. [CrossRef] [PubMed]

55. Halgren, T.A.; Murphy, R.B.; Friesner, R.A.; Beard, H.S.; Frye, L.L.; Pollard, W.T.; Banks, J.L. Glide: A New Approach for Rapid, Accurate Docking and Scoring. 2. Enrichment Factors in Database Screening. J. Med. Chem. 2004, 47, 1750-1759. [CrossRef]

56. Friesner, R.A.; Banks, J.L.; Murphy, R.B.; Halgren, T.A.; Klicic, J.J.; Mainz, D.T.; Repasky, M.P.; Knoll, E.H.; Shaw, D.E.; Shelley, M.; et al. Glide: A New Approach for Rapid, Accurate Docking and Scoring. 1. Method and Assessment of Docking Accuracy. J. Med. Chem. 2004, 47, 1739-1749. [CrossRef]

57. Jacobson, M.P.; Pincus, D.L.; Rapp, C.S.; Day, T.J.F.; Honig, B.; Shaw, D.E.; Friesner, R.A. A Hierarchical Approach to All-Atom Protein Loop Prediction. Proteins Struct. Funct. Bioinf. 2004, 55, 351-367. [CrossRef]

58. Jacobson, M.P.; Friesner, R.A.; Xiang, Z.; Honig, B. On the Role of Crystal Packing Forces in Determining Protein Sidechain Conformations. J. Mol. Biol. 2002, 320, 597-608. [CrossRef]

59. Li, J.; Abel, R.; Zhu, K.; Cao, Y.; Zhao, S.; Friesner, R.A. The VSGB 2.0 model: A next generation energy model for high resolution protein structure modeling. Proteins 2011, 10, 2794-2812. [CrossRef]

60. Bowers, K.J.; Chow, D.E.; Xu, H.; Dror, R.O.; Eastwood, M.P.; Gregersen, B.A.; Klepeis, J.L.; Kolossvary, I.; Moraes, M.A.; Sacerdoti, F.D.; et al. Scalable Algorithms for Molecular Dynamics Simulations on Commodity Clusters. In Proceedings of the 2006 ACM/IEEE Conference on Supercomputing, Tampa, FL, USA, 11-17 November 2006; Volume 84, pp. 11-17.

61. Berendsen, H.J.C.; Postma, J.P.M.; van Gunsteren, W.F.; Hermans, J. Interaction Models for Water in Relation to Protein Hydration. In Intermolecular Forces: The Jerusalem Symposia on Quantum Chemistry and Biochemistry; Pullman, B., Ed.; Springer: Dordrecht, Holland, 1981; Volume 14, pp. 331-342.

62. Nosé, S. A unified formulation of the constant temperature molecular dynamics methods. J. Chem. Phys. 1984, 81, 511-519. [CrossRef]

63. Nosé, S. A molecular dynamics method for simulations in the canonical ensemble. Mol. Phys. 1984, 52, 255-268. [CrossRef]

64. Hoover, W.G. Canonical dynamics: Equilibrium phase-space distributions. Aps Phys. 1985, 31, $1695-1697$. [CrossRef] [PubMed] 
65. Martyna, G.J.; Tobias, D.J.; Klein, M.L. Constant pressure molecular dynamics algorithms. J. Chem. Phys. 1994, 101, 4177. [CrossRef]

66. Moussaoui, O.; Touimi, G.B.; Bennani, B.; Tama, A.B.; Chakroune, S.; Boukir, A. Synthesis of a new serie of quinoline-carboxamides based on methylated aminoesters: NMR characterization and antimicrobial activity. Mediterr. J. Chem. 2019, 9, 326-336. [CrossRef]

67. Jacob, F.; Bernner, S.; Cuzin, F. On the Regulation of DNA Replication in Bacteria. Cold Spring Harb. Symp. Quant. Biol. 1963, 28, 329-333. [CrossRef]

68. Hawkey, P.M. Mechanisms of quinolone action and microbial response. J. Antimicrob. Chemother. 2003, 51, 29-35. [CrossRef]

69. Horowitz, D.S.; Wang, J.C. Mapping the Active Site Tyrosine of Escherichia Coli DNA Gyrase. J. Biol. Chem. 1987, 262, 5339-5344.

70. Gellert, M.; Mizuuchi, K.; O’Dea, M.H.; Nash, H.A. DNA Gyrase: An Enzyme That Introduces Superhelical Turns into DNA. Proc. Natl. Acad. Sci. USA 1976, 11, 3872-3876. [CrossRef]

71. Nakada, N.; Gmunder, H.; Hirata, T.; Arisawa, M. Mechanism of Inhibition of DNA Gyrase by Cyclothialidine, a Novel DNA Gyrase Inhibitor. Antimicrob. Agents Chemother. 1994, 9, 1966-1973. [CrossRef]

72. Bax, B.D.; Chan, P.F.; Eggleston, D.S.; Fosberry, A.; Gentry, D.R.; Gorrec, F.; Giordano, I.; Hann, M.M.; Hennessy, A.; Hibbs, M.; et al. Type IIA Topoisomerase Inhibition by a New Class of Antibacterial Agents. Nature 2010, 7309, 935-940. [CrossRef]

73. Charrier, C.; Salisbury, A.M.; Savage, V.J.; Duffy, T.; Moyo, E.; Chaffer-Malam, N.; Ooi, N.; Newman, R.; Cheung, J.; Metzger, R.; et al. Novel bacterial topoisomerase inhibitors with potent broad-spectrum activity against drug-resistant bacteria. Antimicrob. Agents Chemother. 2017, 61, e02100-e02116. [CrossRef]

Publisher's Note: MDPI stays neutral with regard to jurisdictional claims in published maps and institutional affiliations. 